\title{
SOME SPECIES OF CROTALARIA IN AUSTRALIA
}

\author{
ALma T. LeE
}

(Accepted 7.1977)

\begin{abstract}
Lee, A. T. (National Herbarium of New South Wales, Royal Botanic Gardens, Sydney, Australia 2000) 1978. Some species of Crotalaria in Australia. Telopea 1 (5):319-356.-.The taxa currently or in the past known by the names $C$. dissitiflora Benth. and its vars. rugosa Benth., eremaea (F. Muell.) Benth., and grandifora Benth., C. eremaea F. Muell., C. benthamiana E. Pritzel, C. strehlowii E. Pritzel (Neotype designated), C. novae-hollandiae DC. and its formae lasiophylla Benth. (Lectotype designated), parviflora Benth., and oblongifolia Benth., C. oblongifolia Hook., $C$. crassipes Benth., and $C$. mitchellii Benth. and its var. tomentosa Ewart are critically examined. Changes in circumscription and nomenclature are proposed and the following are recognized: C. benthamiana (Lectotype designated); C. dissitiflora with two subspecies; C. eremaea with two subspecies incorporating $C$. strehlowii; $C$. mitchellii with two subspecies, including subsp. laevis subsp. nov., and $C$. smithiana nom. et stat. nov. replacing $C$. mitchellii var. tomentosa; C. novae-hollandiae with two subspecies incorporating the three formae of Bentham together with C. crassipes, a Lectotype designated for f. lasiophylla; and C. medicaginea again recognized as the correct name for Australian plants now often identified as C. trifoliastrum. Species naturalized in New South Wales are enumerated with some changes in nomenclature resulting from recent work on African species.
\end{abstract}

In preparing an account of the genus Crotalaria for the Flora of New South Wales, several species presented problems requiring consideration of extensive populations partly or even wholly outside this State. Thus $C$. dissitiflora and its var. eremaea have long been recorded for New South Wales, but the populations occurring in this State are now seen to be the southeastern extremities of two very extensive, polytypic species $C$. dissitiflora and $C$. eremaea; the large collections of both in several Australian herbaria are reviewed, more fully described, and their localities mapped. The Western Australian taxon variously known as $C$. benthamiana and $C$. dissitiflora var. grandiflora is re-examined and the relationships of the taxa are briefly discussed.

Similarly, the large collections of both $C$. novae-hollandiae and $C$. mitchellii which have been critically examined show these to be two allopatric species each with an extensive range, in northern and eastern Australia respectively; both are polytypic and of the two only C. mitchellii occurs in New South Wales. C. novaehollandiae is considered to comprise two subspecies, incorporating but not closely corresponding with the forms distinguished by Bentham. Two subspecies are recognized in $C$. mitchellii also, and subsp. laevis subsp. nov. is described. $C$. mitchellii var. tomentosa is raised to specific rank as $C$. smithiana; it resembles C. mitchellii chiefly in having small flowers, but is quite distinct in its unifoliolate (not simple) leaves, and also quite disjunct geographically. 
Distribution maps are provided for all these taxa, which are discussed under the following headings:

1. The $C$. dissitiflora complex

i. C. benthamiana

1i. C. dissitiflora

a. subsp. dissitiflora

b. subsp. rugosa

iii. C. eremaea

a. subsp. eremaea

b. subsp. strehlowii

2. C. mitchellii and C. smithiana

i. C. mitchellii

a. subsp. mitchellii

b. subsp. laevis

ii. C. smithiana

3. C. novae-hollandiae (including C. crassipes)

C. novae- hollandiae

a. subsp. novae-hollandiae (syn. C. crassipes)

b. subsp. lasiophylla

4. C. medicaginea or C. trifoliastrum

C. medicaginea

5. Species naturalized or escaped from cultivation in New South Walesa check list.

In the text below, all specimens cited as Types have been examined unless otherwise indicated; they are not cited again among specimens examined but localities are mapped where appropriate.

Terms used to describe shape of parts are those defined in Chart la of the Systematics Association Committee (1962), and their precise definition is indicated by the formula following in parentheses e.g. (SAC 7-9), also taken from that chart. Flower parts are measured as shown in Fig. 3.

Distribution maps have been compiled from specimens cited, including Types whether seen or not, but where crowding of symbols was confusing, (near) duplicate localities have not been mapped and so the number of citations does not always match the number of symbols for a given taxon. Although an accurate representation of localities has been sought, the scale of symbol and map and lack of precision in data, especially on early labels (some Types), make caution necessary in interpreting some of the localities shown.

The subdivisions or Districts of the Australian States used in the citation of specimens are taken from the following sources:-

Queensland: map of pastoral districts supplied by BRI.

New South Wales: map in Contr. New South Wales Natl. Herb. Fl. Ser. 1-18: 16 (1961).

South Australia: author's preface in J. M. Black, Fl. South Australia ed. 2, 1: 5 (1948), or labels on the sheets in AD. 
Western Australia: map in Gardner, C. A. \& H. W. Bennetts, The Toxic Plants of Western Australia: 206 (1956). West Australian Newspapers, Perth.

Northern Territory: map in Chippendale, Check List of Northern Territory Plants, in Proc. Linn. Soc. New South Wales 96: 209 (1971).

\section{THE C. DISSITIFLORA COMPLEX}

Until recently, large and very extensive populations of Crotalaria in Australia were covered by the name $C$. dissitiflora and, though other names were published and sometimes used for parts of these regional populations, the application of the names and relations within the group were imperfectly understood. It is now evident from the larger collections available that there are three parts of the total population which maintain their distinctness to a high degree. Most of the difficulties which arise in the assigning of a few herbarium specimens I believe to be due to deficiencies in the specimens themselves and lack or confusion of pertinent data, rather than to any real breakdown of isolating mechanisms.

The first part of the complex is (i) C. benthamiana, a monotypic species limited to the Fortescue District of Western Australia where it appears to maintain its distinctness by complete geographic isolation. It is close to one subspecies of C. dissitiflora and like the whole of that species shows a preference for heavy soils. The other major parts comprise the taxa usually known as (ii) $C$. dissitiflora, and (iii) C. eremaea and C. strehlowii, and the morphological differences between these two parts are supported by a largely allopatric distribution and apparently quite rigid preferences for different soils. These soil preferences have long been recognized in Queensland, and were incorporated by the late L. S. Smith in a working key to species of Crotalaria in Australia which he compiled for herbarium use. C. dissitiflora occurs, as is indicated by many collectors, only on heavy, often dark soils, while $C$. eremaea (here including $C$. strehlowii) is nearly always found on sand.

(ii) $C$. dissitiflora, as recognized here, comprises two geographic races. One is largely tropical, from the Ord District of Western Australia to Queensland, and the other subtropical in Queensland and New South Wales. Names are already published for these races, but not in the subspecific category which I consider is here so clearly indicated, and new combinations are therefore provided below. Subsp. dissitiflora is well documented as to the heavy soils on which it occurs; we have less information about the other subspecies, but those specimens which are annotated or from known soils indicate a similar preference for heavy soils, in the Northern Territory and Western Australia, as well as in Queensland.

Within C. dissitiflora, subsp. dissitiflora is distinguished from subsp. rugosa chiefly by the length and density of pubescence with a resultant appearance of the venation, and intergradation between the subspecies is shown in these characters (see $C$. dissitiflora, Distribution).

(iii) The third major part of the total population is very widespread in eremean parts of Western Australia, the Northern Territory and South Australia. As in C. dissitiflora, there are two components, here clearly distinguished over most of their extensive range and, predictably, already named in specific rank--as C. eremaea 
(1859) and C. strehlowii (1918). There are, however, a number of herbarium specimens which do not fall comfortably into either of these components and which have mostly been found in the zone of contact between them. Nevertheless, great dissimilarity between the largely stabilised extremes of the variation permits a division on morphological characters which, while partly arbitrary, does correspond broadly with geographic distribution and features of habitat, and these last factors could be expected to operate towards further isolation of the two components. The arguments for recognition of the two in specific as against subspecific rank seem, in fact, to be almost equally tenable, but I propose to adopt the treatment which more clearly reflects the biological situation, i.e. to recognize a single species, $C$. eremaea, with two imperfectly discrete geographic subspecies.

Between these two subspecies the most reliable diagnostic character is leaflet form, which is largely correlated with density and extent of pubescence. There are also differences in flower size and form in the species, as there are in C. dissitiflora, but in $C$. eremaea the number of variants is greater and there is poorer correlation with other characters. The Central Australian plants (subsp. strehlowii) probably have the largest "straight" flowers, while the Simpson Desert populations (mostly subsp. eremaea) more often display the small "round" form of flower (Figs. 1, 2), though there are many exceptions to this generalization and the difference is influenced by age of flower and early pod development. While both subspecies of $C$. eremaea occur on sandy soils, the Type subspecies is most common in large communities of the Simpson Desert and its extensions; specimens of the other subspecies are more often annotated as from creek or river bed or bank, as well as from sandhills of Central Australia. Little is known yet of Western Australian occurrences except that most of the few collections are from the southern half of the eremean Carnegie District, where sandy soils of the Great Victoria and Gibson Deserts are predominant. Intergradation between the subspecies occurs commonly along their zone of contact, northwards from Spencer's Gulf.

It seems probable that $C$. benthamiana, $C$. dissitiflora and $C$. eremaea have evolved from a common stock, diverging under the influence of changing climatic and geographic conditions, and that the derivatives have become stabilized genetically in relation to the nature of the soil and to geographic isolation. In the Northern Territory, where $C$. dissitiflora subsp. rugosa is occasionally sympatric with $C$. eremaea subsp. strehlowii, there appears to be complete discontinuity. Further south in Western Australia, there is no known contact of either $C$. benthamiana or $C$. dissitiflora with $C$. eremaea, although paucity of collections from some $700 \mathrm{~km}$ of intervening desert may be obscuring a greater propinquity than is at present apparent. Thus, in spite of some confusion, $I$ believe there is at least a very nearly complete discontinuity between these species, even between $C$. dissitiflora and $C$. eremaea, and indeed the great majority of the large collections of this whole complex can be confidently assigned to their species. But there have been difficulties in specific separation, and for some time a very few specimens, with unquestionable characters of $C$. dissitiflora from areas in which $C$. eremaea clearly predominates, threatened to make nonsense of the taxonomic arrangement which so many other collections had supported. Some of these difficulties arose in areas where different soils are encountered in relatively small patches or tongues, and $C$. dissitiflora was in fact on a tongue of heavy soil in a wider area of sand characteristically inhabited by $C$. eremaea. It is possible that three isolated collections from Central Australia, 
in the very heart of the $C$. eremaea subsp. strehlowii population, may prove to represent small disjunct populations of $C$. dissitiflora persisting in patches, including gilgais, of heavy soils recently mapped for nearby areas (Stephens 1961, Jackson 1962, Litchfield 1969). They could possibly, though not probably, be relics of a few plants introduced for garden cultivation. Whatever the explanation, the following three specimens are $C$. dissitiflora subsp. dissitiflora on morphological grounds (the third with some reservations) and, though separated by vast distances across sandy areas from the main population, are at least in the right latitudes for this subspecies: Chippendale NT 4080, Johnson NT 55, Latz 158: see citations under C. dissitiflora subsp. dissitiflora from Northern Territory, and Map 1 (see p. 330).

The other serious problem arose in assigning three specimens from the "corner country" of Queensland and South Australia. Two of these were collected from brown loam soils (the third lacks information on soil) which are atypical for either species. The dominant Crotalaria in this area is C. eremaea subsp. eremaea but the morphology of these specimens is closest to that of $C$. dissitiflora subsp. rugosa which is not known so far south. The conviction persists however, that they are part of the $C$. eremaea population, though more knowledge concerning local soils (cf. Stephens, 1963) and their possible effects on morphology in this group may require revision of this opinion. The possibility of incomplete discontinuity in this zone must also remain for consideration. The three specimens are cited under C. eremaea subsp. eremaea marked *, and shown on Map 1: Johnson 73/134, Johnson 73/139, Basedow 51.

TABLE 1

DIFFERENCES BETWEEN C. BENTHAMIANA, C. DISSITIFLORA AND C. EREMAEA

\begin{tabular}{|c|c|c|c|c|}
\hline & & & C. dissitiflora and $C$. benthamiana & C. eremaea \\
\hline Plants & . & . & $\begin{array}{l}\text { Usually branched (and regenerating) } \\
\text { from deeply sited, } \pm \text { congested, } \\
\text { ascending underground parts; to } \\
\text { c. } 0.5 \mathrm{~m} \text { in height. }\end{array}$ & $\begin{array}{l}\text { Often branched from a main stem, } \\
\text { apparently individual plants, but at } \\
\text { least sometimes connected by (and } \\
\text { regenerating from) extensive } \pm \\
\text { horizontal underground parts; } \\
\text { usually } 0.5-1 \mathrm{~m} \text { in height. }\end{array}$ \\
\hline Leaves & . & $\ldots$ & $\begin{array}{l}\text { Rather thin, not wrinkling on drying; } \\
\text { always with some pubescence } \\
\text { below, glabrous to densely pubes- } \\
\text { cent above, the upper surface at } \\
\text { least and where visible through the } \\
\text { pubescence, minutely dotted. }\end{array}$ & $\begin{array}{l}\text { Rather thick, in texture or at least by } \\
\text { virtue of dense pubescence, wrink- } \\
\text { ling on drying if surface visible; } \\
\text { glabrous to densely tomentose with } \\
\text { many intergrades; leaf surface } \\
\text { where visible minutely pitted or } \\
\text { wrinkled rather than dotted. }\end{array}$ \\
\hline Leaflets & . & .. & $\begin{array}{l}\text { Generally narrow-elliptical to -ovate, } \\
\text { the laterals like the terminal and not } \\
\text { less than half its length. }\end{array}$ & $\begin{array}{l}\text { Generally narrow-oblong to trullate, } \\
\text { the laterals if present usually much } \\
\text { reduced, sometimes almost circular, } \\
\text { or at most half as long as the ter- } \\
\text { minal. }\end{array}$ \\
\hline Stipules & . & .. & $\begin{array}{l}\text { Present on at least some leaves, usually } \\
1-5 \mathrm{~mm} \text { long (rarely less than } 1 \\
\mathrm{~mm} \text { ), curved-spreading. }\end{array}$ & $\begin{array}{l}\text { Usually absent, or less than } 1.5 \mathrm{~mm} \\
\text { long, rarely to } 4 \mathrm{~mm} \text { and then not } \\
\text { usually spreading. }\end{array}$ \\
\hline Flowers & . . & $\ldots$ & $\begin{array}{l}\text { In C. dissitiflora: Almost always small } \\
\text { and "round" (Fig. 1), 8-11 mm } \\
\text { long, rarely c. } 14 \mathrm{~mm} \text {. } \\
\text { In C. benthamiana: Long-beaked and } \\
\text { "straight" (Fig. 2), 15-17 mm long. }\end{array}$ & $\begin{array}{l}\text { "round" or "straight", } 12-15 \quad(-18) \\
\text { mm long. }\end{array}$ \\
\hline
\end{tabular}




\section{KEY TO THE SPECIES OF THE C. DISSITIFLORA COMPLEX}

(See also Table 1)

1. Leaves always trifoliolate, the lateral leaflets at least half as long as the terminal. Plants $20-30(-40) \mathrm{cm}$ high, on heavy soils.

2. Flowers large, $15-17 \mathrm{~mm}$ long, the keel with a straight beak extending forward and not incurved (Fig. 2). In the Fortescue District of Western Australia ....

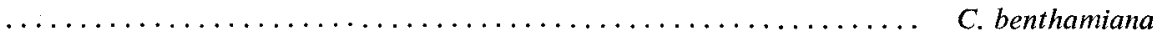

2.* Flowers smaller, mostly 8-11 mm long, the keel rounded with a slightly incurved beak (Fig. 1). In the Ord District of Western Australia, tropical Northern Territory and Queensland, and subtropical Queensland and New South Wales. .

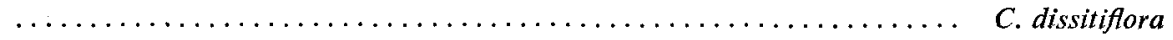

$1{ }^{*}$ Leaves unifoliolate, or if trifoliolate the lateral leaflets usually much reduced or less than half as long as the terminal (but rarely, along S.A.-N.S.W. and -Q. borders and in W.A., about half as long as the terminal). Flowers various in form. Plants to c. $1 \mathrm{~m}$ high, on sandy soils. In eremean parts of southern Western Australia, Northern Territory, Queensland and New South Wales ...................... eremaea

1 i C. benthamiana Pritzel in Diels \& Pritzel in Bot. Jahrb. Syst. 35: 267 (1904); Gardner, Enum. Pl. Austral. Occ.: 62 (1930); Beard, (Descr. Cat.) W. Austral. Pl.: 45 (1965) and ed. 2: 65 (1970). - C. dissitiflora var. (?) grandiflora Benth., Fl. Austral. 2: 184 (1864). TYPE: Typification of this taxon poses a problem of interpretation. Pritzel's protologue, while stating unequivocally that his name, $C$. benthamiana, was that of a new species, also explicitly embraced the taxon previously described by Bentham. His publication could therefore legitimately be considered to comprise a new name and new status rather than a new species, and in this case the Type would be that of Bentham's variety. Either argument could be upheld, but since Pritzel's cited specimen has not been available to me and is presumed destroyed in $\mathrm{B}$, it is convenient to consider the circumscription of $C$. benthamiana to embrace all three of the specimens cited by the two authors as Syntypes, and from them to select a Lectotype. In this case there is no reason to doubt that all are conspecific. SYNTYPES: (i) Hammersley [Hamersley] Range [Western AustraliaFortescue], M.B. [i.e. Maitland Brown, collector with F. Gregory's Expedition to the North-West] (MEL 1010368, "seen by Bentham"; also a print at NSW of CSIRO Neg. No. Kew 1121); (ii) not seen: Port Nichol and De Gray R [Western AustraliaFortescue], Ridley's Expedition; (iii) not seen, believed destroyed in $\mathrm{B}$ : in the tropical region from Nickol Bay to Spring Station [Western Australia-Fortescue], in dry gravelly hills, fruiting April, E. Pritzel (?B). LECTOTYPE, here designated: (i) above, cited as "Hammersley Range, $F$. Gregory's Expedition".

[C. dissitiflora sensu auctt., non Benth. sensu str.: Mueller (1862) in part, viz. the Hamersley Range Type (see also C. dissitiflora subsp. rugosa), in reference below; Beard, Wildfl. Northwest: 9, 28 (c. 1972). These authors here used C. dissitiflora for C. benthamiana which they regarded as a part of C. dissitiflora].

Soft-wooded perennials, apparently (from the few specimens available) identical in habit with $C$. dissitiflora, the leaves always trifoliolate (except the earliest), petiolate and stipulate, the stipules usually persistent and spreading. Leaflets of thin texture but quite densely clothed with loosely appressed shining hairs partly obscuring the minute dotting of both surfaces; lateral leaflets at least half as long 
as the terminal, all elliptical (SAC 2-4) or obovate (SAC 46-48) to oblong (SAC 1516), a few showing the weakly bullate effect of the pubescence and venation seen in C. dissitiflora subsp. rugosa. Inflorescences terminal on stems and branches, as in C. dissitiflora. Flowers clear yellow without markings, larger than in the related taxa, long and "straight" (Fig. 2) in form. Calyx broadly campanulate, with five subequal teeth slightly exceeding the tube and the very short receptacle, pubescent, with a pair of very small bracteoles inserted on the receptacle. Standard broadovate to almost circular. Wings without a distinct auricle. Keel somewhat angular with the beak extended forward and not incurved, the claw very short. Ovary pubescent; fruits and seeds not seen.

Terminal leaflets c. $2-4 \mathrm{~cm}$ long. Stipules 2-5 mm long. Flowers $15-17 \mathrm{~mm}$ long, pedicels $2-5 \mathrm{~mm}$, much exceeding the bracts, c. $2 \mathrm{~mm}$. Calyx c. $5 \mathrm{~mm}$ long, bracteoles $0.5-2 \mathrm{~mm}$ long. Standard 11-15 mm long, 13-16 mm broad, the claw c. $2 \mathrm{~mm}$. Wings $12-13.5 \mathrm{~mm}$ long, the claw c. $2 \mathrm{~mm}$. Keel 12-16 mm long, 5-5.5 $\mathrm{mm}$ broad, on a claw $1-1.5 \mathrm{~mm}$ long.

Distribution (see Map 1): Known only from the Fortescue District of Western Australia, from near the coast to Wittenoom and Mt Tom Price inland; early collections are annotated "Tableland, Rocky" and "dry gravelly hills" while later records (J. S. Beard, pers. comm.) indicate "red [basalt] soil, a cracking clay giving rise to a very uneven "crab-hole plain"".

Specimens Examined: Western Australia: Northern Province-Fortescue: Port Walcott, Harper (MEL; a sheet at PERTH ex MEL with this label is mixed, but the fragment marked $\beta$ appears to be a duplicate of the collection at MEL, the others probably samples of other MEL collections of $C$. dissitiflora); Nickol R, Forrest 1878 (MEL); between Onslow and Roebourne at "Karratha" Station, Dampier, Godlonton 8-9.1968 (PERTH); "Karratha" Station, between Onslow and Roebourne, Fitzgerald 10.1968 (PERTH); Fortescue R, Carey 1878 (MEL); Wittenoom, on Port Hedland road, Garstone 7.1964 (PERTH); between Port Hedland and Mt Tom Price, Donovan 3.1970 (BRI).

The status of this taxon is debatable; vegetatively it is indistinguishable from C. dissitiflora subsp. rugosa, though in their flowers these two taxa are virtually constant and different from one another (except for rare collections from Queensland, marked * in citations of subsp. rugosa); they are, moreover, geographically disjunct. Since soil preference serves so notably to distinguish $C$. dissitiflora from $C$. eremaea, it is significant that $C$. benthamiana grows on heavy soils, though its flower form is not uncommon among the varying forms seen in $C$. eremaea. Nevertheless there are differences between the grey and black soils preferred by $C$. dissitiflora and the red basaltic soils of the Pilbara (a region corresponding in large part with the Fortescue District) described by Beard, and others recorded by Beadle (pers. comm. as "redbrown sandy clay with lime" from near Port Hedland), and Stephens (1963: heavy brown soils from the Fortescue $\mathrm{R}$ just north of the Hamersley Range). These differences, according to Beard, are associated with lower rainfall in the Pilbara. Thus $C$. benthamiana shows some affinities with $C$. dissitiflora, as well as some differences, and this is a situation recognized in other taxa separated into Pilbara and Kimberley occurrences. Here there appears to be almost complete morphological discontinuity in floral characters $\uparrow$ supported by an allopatric distribution, while the subspecies of $C$. dissitiflora show a slighter degree of difference with probably considerable intergradation. 

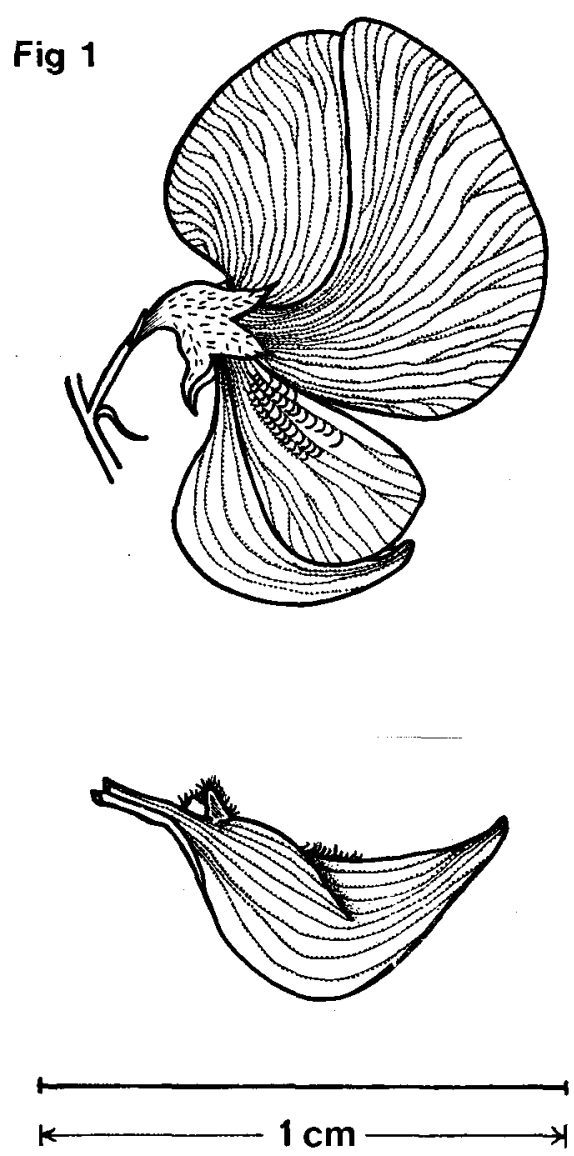

Fig. ${ }^{\text {1. }}$. An extreme example of the "small, round flower", and keel (from a different flower). 

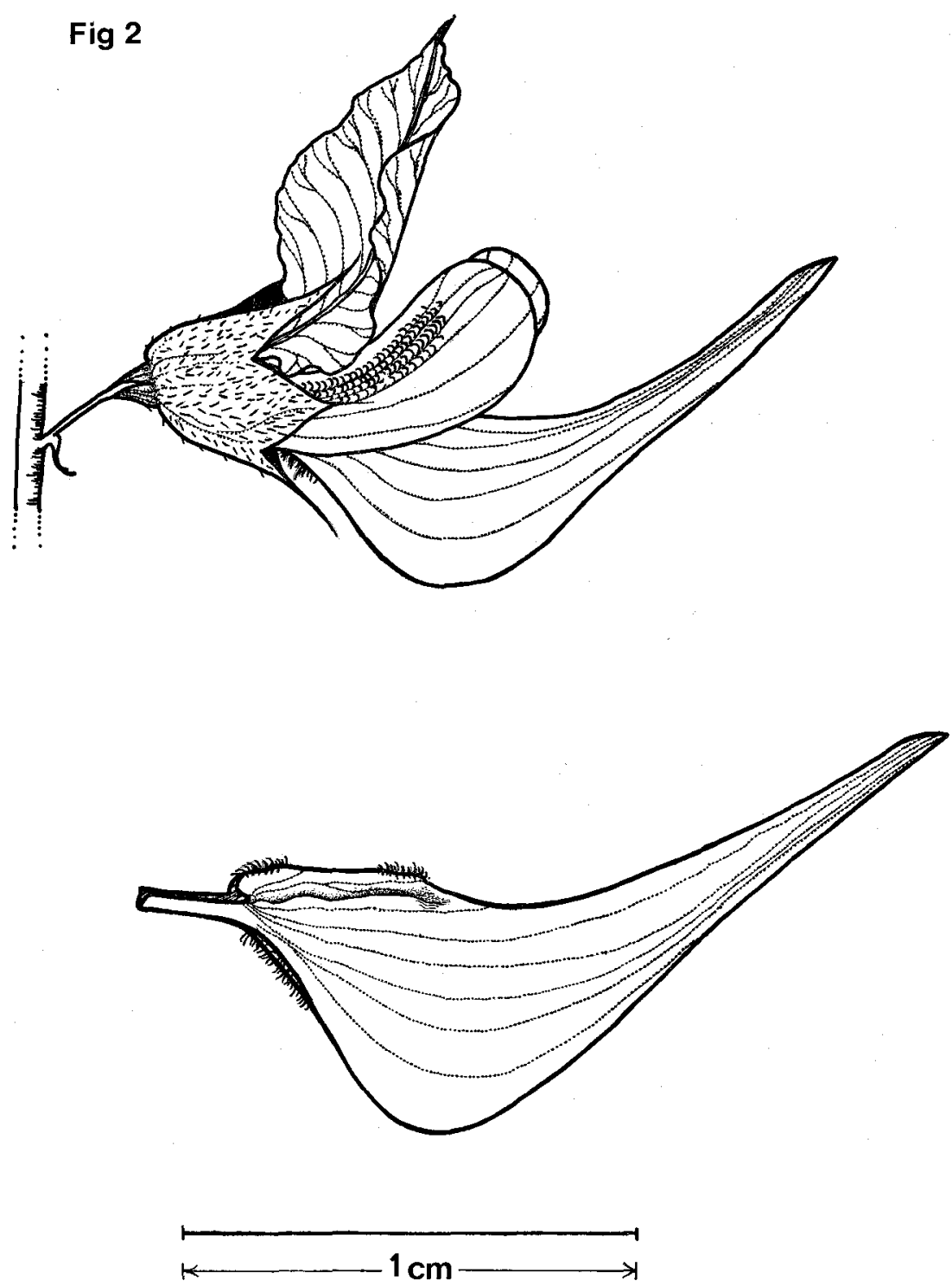

Fig. 2. An extreme example of the "long, straight flower", and its keel. 


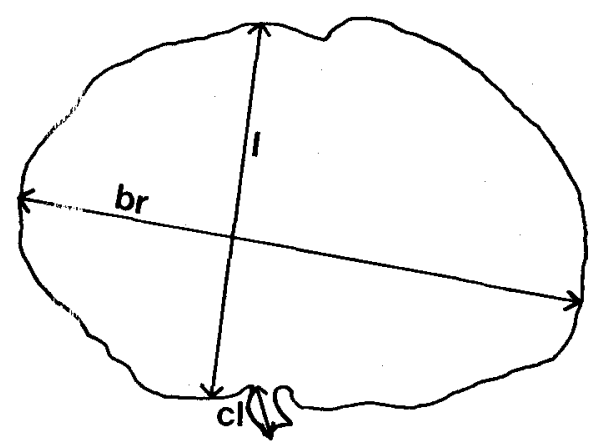

standard

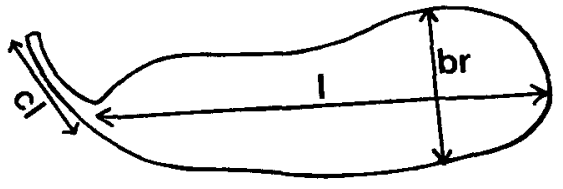

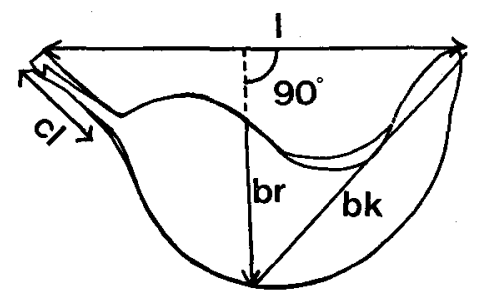

keel

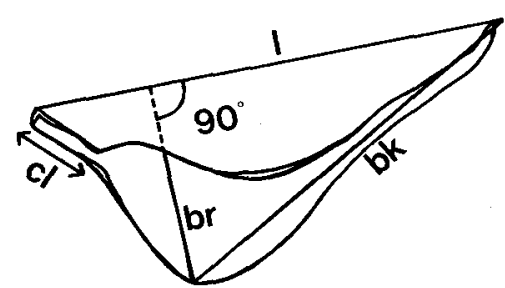

wing

Fig. 3. Diagrams showing method of measuring the petals: $\mathrm{cl}$ claw; standard and wing: 1 maximum length excluding claw; br maximum breadth; keel: 1 length $\&$ br breadth as shown; bk beak.

1 ii C. dissitiflora Benth. in Mitch., Trop. Australia: 386 (1848); Bentham, Fl. Austral. 2: 184 (1864) excl. var. eremaea; F. Mueller, Fragm. 3: 56 (1862), and Fragm. 9: 156 (1875) excl. var. eremaea; Moore \& Betche, Handb. Fl. New South Wales: 145 (1893) excl. var. eremaea; F. M. Bailey, Queensland Fl. 2: 376 (1900) excl. var. eremaea; Maiden \& Betche, Census New South Wales Pl.: 106 (1916) excl. var. eremaea; Ewart \& Davies, Fl. N. Territory: 141 (1917) excl. "glabrous form . . . Hill No. 54"; Domin in Biblioth. Bot. 22 (892): 735 (1925) excl. reference to South Australian occurrence; Polhill in Kew Bull. 22: 247 (1968) excl. synonymy. HoLotype: Baloon [Balonne] R [Queensland-Maranoa], Mitchell, 17 Nov. 1846 (No. 459, K, print at NSW of CSIRO Neg. No. 1118). The Type sheet bears three specimens but, from details given in the text of Mitchell's journal, only that cited can be the Holotype. A second, No. 379, bears a collection date (somewhat ambiguous but possibly applying to both the numbers on its label) previous to that mentioned in Bentham's description, while the third is undated (Herb. Hookerianum) but possibly an Isotype. Two specimens, matched with No. 459 above by Mr L. Pedley while Australian Botanical Liaison Officer at Kew, have been examined on loan (marked $*$ in citations).

See under the subspecies for synonymy.

$\dagger$ See C. dissitiflora subsp. rugosa in key, p. 331. 
References in the literature under this name seem, so far as can be ascertained from their content, localities cited, or areas treated, rarely to apply to the taxon in the sense adopted here. Now that $C$. dissitiflora is seen as specifically distinct from $C$. benthamiana and $C$. eremaea, the name $C$. dissitiflora becomes "misapplied" when used for all or part of these taxa as follows:

[C. dissitiflora was misapplied by Black (1948) and Eichler (1965) to the polytypic species C. eremaea q.v.; by Tate (1890) to C. eremaea subsp. eremaea q.v. (or perhaps to C. eremaea as a whole); by Tate (1896), Ewart \& Davies "glabrous form" (1917), Gardner (1930) and Beard (1970), to C. eremaea subsp. strehlowii, q.v.; and by Beard (c. 1972) to C. benthamiana q.v.].

Soft-wooded perennials of small stature, usually less than $30 \mathrm{~cm}$ high, with a system of deeply sited and rather congested, ascending underground structures (histologically roots by comparison with $C$. eremaea) from which regeneration occurs after adverse climatic periods or disturbance such as ploughing. Stems several from the base, erect or decumbent, at first densely pubescent with loosely appressed silvery hairs becoming sparse and brownish with age. Leaves always trifoliolate (after the primary, and perhaps also early leaves on regenerating stems), petiolate and stipulate; stipules linear, characteristically spreading, persistent on at least some leaves, but small and sometimes obscured, or fallen from old, dried specimens. Leaflets of rather thin texture, elliptical to ovate or obovate (SAC 2-3, 37-39 or 46-48), the laterals at least half as long as the terminal, variously pubescent, the upper or both surfaces minutely dotted (when visible through the pubescence). Inflorescences terminal on stems and branches, racemes of about 10-20 flowers on axes usually a little longer than their peduncles. Flowers with rare exceptions, small and "round" (Fig. 1), clear golden yellow without other colouring or markings, pedicellate in the axils of small, finally recurved bracts. Calyx broadly campanulate, with five subequal teeth, the upper two usually a little shorter and narrower than the lower three, slightly exceeding the tube; tube slightly longer than and contracted into a short, basal receptacle; bracteoles minute, inserted usually near the top of the receptacle. Standard glabrous, nearly circular but slightly broader than long, scarcely auriculate, the calli extending on to the short claw, the apex shortly retuse or with a point in the indentation. Wings rounded-oblong to triangular, without a distinct auricle. Keel rounded, the beak slightly incurved. Ovary pubescent or hoary but sometimes apparently glabrous on the sides, with a more or less broad band of longer, rather coarse hairs along the upper suture, especially at its distal end. Style in a geniculate curve within the keel, bearded only on the inner side. Pod sparsely pubescent all over with short hairs outside, the sutural band now scarcely distinguishable, glabrous and shiny inside, oblong-clavate, tapered asymmetrically into a slender stipe. Seeds rarely seen mature on herbarium specimens though many apparently fully grown pods are present, only slightly longer than broad, yellow-ochre in colour with a marked but scarcely hooked radicular lobe, the surface almost smooth.

Terminal leaflets often 15-30 (-40) mm long. Stipules (0.5-) 1-3 (-5) mm long. Rachis of inflorescence 6- more than $16 \mathrm{~cm}$, peduncle 2- more than $10 \mathrm{~cm}$ long. Flowers mostly $8-11 \mathrm{~mm}$, rarely $-14 \mathrm{~mm}$ long; pedicels $2-3 \mathrm{~mm}$, bracts $1-2.5 \mathrm{~mm}$ long. Calyx c. $5 \mathrm{~mm}$, bracteoles to c. $1 \mathrm{~mm}$ long. Standard (6.5-) 7-9 (-10.5) $\mathrm{mm}$ long and (7-) 8-11 (-14) mm broad, the claw c. $2 \mathrm{~mm}$. Wings 7-9 (-10) $\mathrm{mm}$ long, 3-5 mm broad, the claw 1-3 mm. Keel 7-10 (-12) $\mathrm{mm}$ long, 4.5-6 mm broad, the claw 1-1.5 mm. Pod often 15-25 mm long, 5-8 mm diam., stipe 5-7 mm; seeds $2-3 \mathrm{~mm}$. 


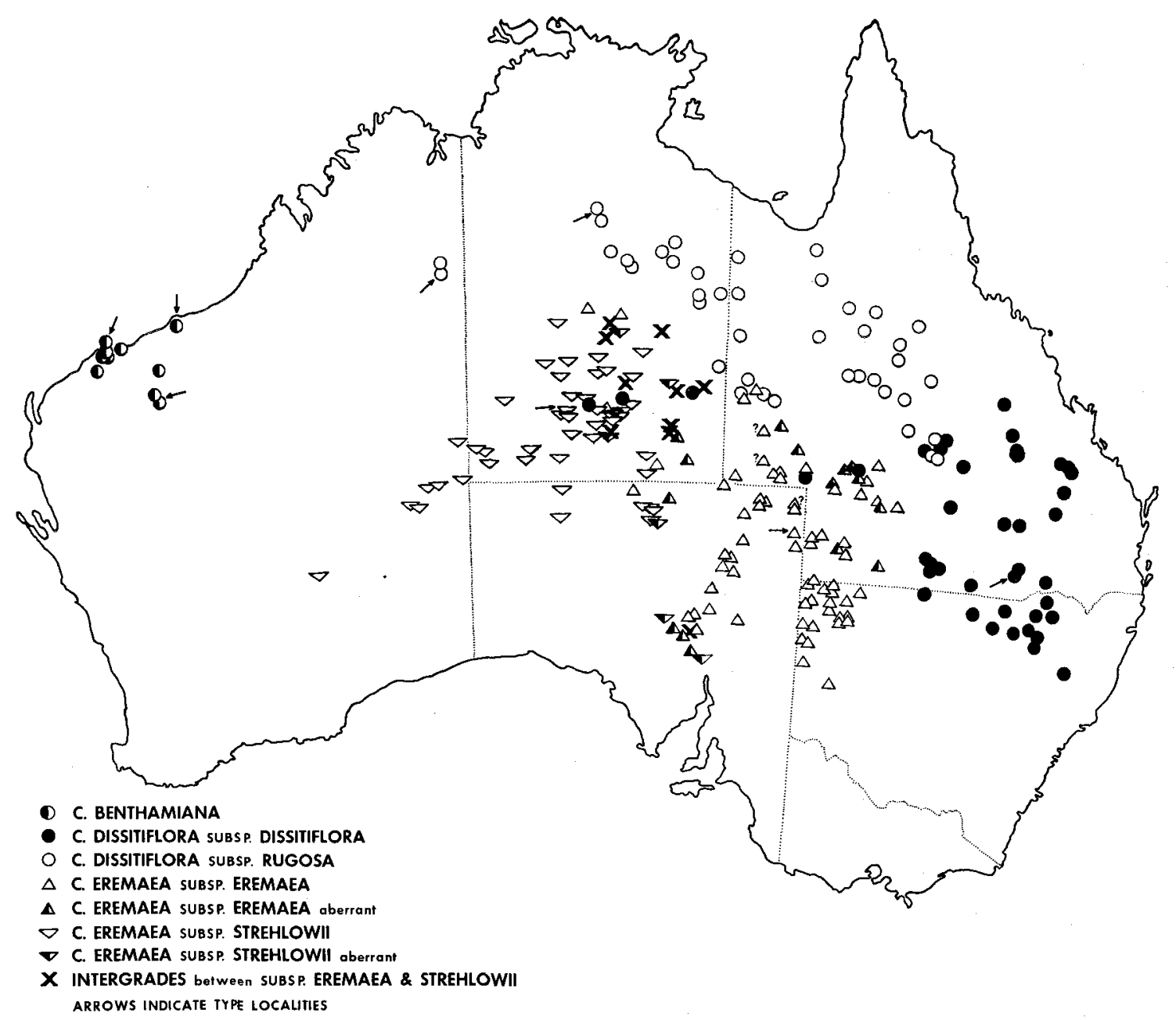


Distribution (see Map 1): Across tropical Australia, from the Ord District of Western Australia to the Northern Territory and Queensland (subsp. rugosa), and into subtropical Queensland and New South Wales (subsp. dissitiflora), but not reaching the coast in the east.

This species falls into two subspecies between which there is probably considerable intergradation, but allocation of specimens to their subspecies depends ultimately on two somewhat inexact characters, the length and density of the pubescence. Many of the specimens available are inevitably rather weatherbeaten, coming from areas of erratic and severe climatic conditions, and it is often difficult to judge the true nature of the plants represented. Thus application of subspecific names here has sometimes been arbitrary and, though indicated in the citations, the intergradant specimens are not distinguished on the map. Nevertheless a zone of intergradation can be detected chiefly in the Gregory South and Mitchell Districts of Queensland and is seen particularly in specimens from around Blackall.

Another aspect of this intergradation is that it has been more apparent in the western part of the specific range than in the eastern, and it is in this western area that $C$. dissitiflora abuts upon $C$. eremaea. It may be significant, in view of the possibly imperfect discreteness of these species, that the same two characters help to separate the species as distinguish the two subspecies of $C$. dissitiflora. For if the primary diagnostic character of the leaflets (see key on p. 324) is not decisive, then a specimen of indeterminate length and density of pubescence may appear either as an intergrade between the species, $C$. dissitiflora (subsp. dissitiflora) and $C$. eremaea (subsp. eremaea), or equally between the two subspecies (dissitiflora and rugosa) of $C$. dissitiflora. Other distinguishing characters, e.g. the greater stature and less congested habit of $C$. eremaea, and the soil preferred, are often not shown by herbarium specimens, and considerable field and experimental work may be necessary to solve this problem with any finality.

In this treatment, the species are separated as in Table 1, and in the key on p. 324, while the subspecies of $C$. dissitiflora are distinguished as follows:

1. Plants with rather scanty pubescence of short, appressed hairs c. $0.5 \mathrm{~mm}$ long. Leaflets always glabrous above and minutely dotted at least above and usually on both surfaces, the veins not dividing raised areas. Flowers small (mostly $8-11 \mathrm{~mm}$ long) and "round" (Fig. 1); keel with a short, often slightly incurved beak. Mostly subtropical, in the southeastern part of the range ............. subsp. dissitiflora a.

1.* Plants with moderate to dense pubescence of rather long, loosely appressed, shining hairs c. $2 \mathrm{~mm}$ long on stems and leaves, though leaflets sometimes glabrous above, especially when old; young leaflets often but not always with a rather weakly bullate ("rugose") appearance from arrangement of pubescence at veins. Flowers as in subsp. dissitifora, 6-10 $\mathrm{mm}$ long (very rarely $-14 \mathrm{~mm}$ and approaching the "straight" form*). Tropical and occasionally subtropical, in the northwestern part of the range

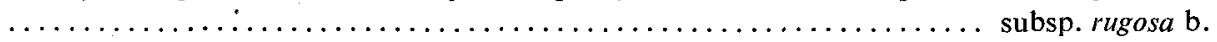

1 ii a subsp. dissitiflora.-C. dissitiflora var. dissitiflora; Chippendale in Proc. Linn. Soc. New South Wales 96: 239 (1972).

[C. dissitiflora sensu auctt., non Benth. sensu str.: ? Mueller (1875) in part (see also subsp. rugosa); Moore \& Betche (1893); Bailey (1900) excl. var. rugosa; Maiden \& Betche (1916); Domin (1925) in part (see also subsp. rugosa); in references above. These authors there used the binomial for that part of the species occurring in the area they treated, viz. subsp. dissitiflora, though their descriptions sometimes covered other elements].

\footnotetext{
* These specimens are marked $*$ in the citations of subsp. rugosa and approach the form seen in
} C. benthamiana. 
Diagnostic characters as given in the key. Keel 8-10 (-12) mm long, 3-5 (-6) $\mathrm{mm}$ broad, the beak 6.5-8 (-9.5) $\mathrm{mm}$ long.

Distribution: Inland parts of subtropical Queensland and northern New South Wales, on "black" and other heavy soils, and apparently in a few disjunct localities providing similar habitats in the Northern Territory.

Specimens Examined: Queensland: Mitchell: "Vinetree Downs", 16 miles $[25 \mathrm{~km}] \mathrm{NE}$. of Blackall, Swinburne 2.1940 (BRI); "Malvern Hills", 22 miles [35 km] W. of Blackall, Everist 2021, 2.1940 (BRI); Blackall, Ranking (BRI); "Tambo" Station, E. of Tambo, Smith \& Everist 876, 10.1940 (BRI). Leichhardt: Clermont, Kearney 12.1940 (BRI); 30 miles [48 km] N. of Springsure township, Story \& Yapp 254, 9.1962 (BRI, MEL, NSW); "Karingal", Springsure, 12 miles [20 km] N. of Springsure-Rolleston road, Gifford 5.1964 (BRI); 10 miles [16 km] S. of Springsure on road to Rolleston, Johnson \& Blaxell 953, 11.1972 (NSW); c. 15 miles [c. $24 \mathrm{~km}]$ S. of Moura on road to Theodore, Henderson 245, 3.1967 (BRI*, MEL, K); Dawson district, Bancroft 11.1915 (BRI); Theodore district, James 1, 1.1956 (BRI); Mt Rose, 25 miles [40 km] NE. of Taroom, Johnson 1664, 5.1960 (BRI); "Richon", 38 miles [61 km] S. of Taroom, Webster 12.1961 (BRI). Gregory South: Windorah, 25 $26^{\prime} \mathrm{S}, 142^{\circ} 39^{\prime} \mathrm{E}$, Cockburn BPS 42, 7-8.1969 (BRI); 2 miles [3 km] from Betoota, Beadle NSW 113668, 5.1963 (NSW)†. Warrego: c. 1 mile [c. $1.6 \mathrm{~km}$ ] S. of Charleville, Rodd 52, 8.1964 (NSW); Cunnamulla, Copeman 4.1963 (BRI), White 11801, 3.1941 (BRI); "Gilruth Plains" to Cunnamulla, Martensz CSIRO W/L Herb. 3938, 12.1967 (BRI); "Gilruth Plains", Cunnamulla, McKee 10313, 4.1963 (NSW, BRI); 6 miles $[10 \mathrm{~km}$ ] on Cunnamulla-Barringun road, Ebersohn E149, 4.1962 (BRI). Maranoa: between Amby and Eurella, Hubbard \& Winders 6366, 1.1931 (BRI, K); Roma, Stevens 2.1958 (BRI); St George, Winn 5.1894 (BRI); Curriwillighi, Dalton NSW 45876 (NSW). Darling Downs: 3 miles [5 km] E. of Toobeah, Pedley 1190, 1.1963 (BRI)*.

New South Wales: Western Plains: $10 \mathrm{~km}$ W. of Barringun, Mills \& Cox 211, 3.1975 (NSW); Moree-Boggabilla road, Jackson NSW 115136, 5.1972 (NSW); Collarenebri, Waterhouse NSW 45852, 9.1950 (NSW); Moree, Mactier NSW 113667, 2.1969 (NSW), Cutting NSW 113670, 2.1961 (NSW); County Narran, Beadle 3.1942 (SYD); Walgett, per Glenfield Veterin. Res. Sta. 43/350, 2.1943 (NSW); "Omco", Burren Junction, Mitchell NSW 11363, 2.1967 (NSW); "Boolcarrol", Breakwell NSW 113662, 4.1967 (NSW); 17 miles [27 km] N. of Narrabri, Walker NSW 116650, 3.1976 (NSW); Narrabri, Crogan NSW 48928, 2.1955 (NSW). North Western Slopes: Tamworth, Barnier NSW 45863, 3.1953 (NSW).

Northern Territory: Central Australia: the following three specimens do not come within the normal geographic range of $C$. dissitiflora subsp. dissitiflora; see comments on p. 322-3: 5 miles [8 km] W. of "Tarlton Downs" homestead, Latz 158, 2.1968 (NSW, MEL); 17 miles [27 km] W. of Arltunga, Chippendale NT 4080, 3.1958 (PERTH); near old "Hamilton Downs" homestead, Johnson NT 55, 10.1956 (AD).

1 ii b subsp. rugosa (Benth.) A. Lee, stat. nov.--C. dissitiflora var. rugosa Benth., Fl. Austral. 2: 184 (1864); F. M. Bailey, Queensland Fl. 2: 376 (1900); Chippendale in Proc. Linn. Soc. New South Wales 96: 239 (1972). IsosyntyPes: (i) Sturts Creek [Western Australia-Ord], F. Mueller 2.1886 (MEL 1010367, "seen by Bentham"); also a print at NSW of CSIRO Neg. No. Kew 1120; (ii) Newcastle Water [Northern Territory-Barkly Tableland], [F. Mueller] (MEL 1010366, "seen by Bentham").

[C. dissitiflora sensu auctt., non Benth. sensu str.: Ewart \& Davies (1917) excl. "Glabrous form . . . Hill No. 54 . . ."; Domin (1925) in part (see also subsp. dissitiflora); Mueller (1862) in part (see also C. benthamiana) and (1875) ? in part (see also subsp. dissitiflora); in references above. These authors there used the binomial for that part of the species occurring in the area they treated, viz. subsp. rugosa].

See Holotype paragraph p 328.

? intergrade between subspecies. 
Diagnostic characters as given in the key. Distinguished from subsp. dissitiflora chiefly by the pubescence of its leaves and stems, the hairs longer, dense at least on the underside of the leaflets and often on both sides, but less dense when old, and sometimes lacking on the upper leaf surface.

Distribution (see Map 1): Tropical and occasionally subtropical; in Queensland, the Northern Territory and the Ord District of Western Australia, on heavy soils including some derived from limestones.

Specimens Examined: Queensland: Burke: Flinders Range, N. Queensland [sic; ?Flinders $\mathrm{R}$, as mapped], Browne NSW 45875, 2.1914 (NSW); Flinders R, White 8.1916 (BRI, NSW 45865); Barkly Tableland (? Q.), Dunn 19, 3.1934 (BRI); Camooweal, Bailey NSW 45856 (NSW); "Sutherland", 60 miles [97 km] NW. of Maxwellton, Nelson \& Entwistle 34, 4.1963 (BRI); "Sommerville", 50 miles [80 km] NE. of Maxwellton, Entwistle 17, 5.1963 (BRI); "Silver Hills", Richmond, Mahoney 3, 4.1957 (BRI); "Wongalee", c. 50 (sic) miles [c. $80 \mathrm{~km}$ ] N. of Hughenden, $20^{\circ} 30^{\prime} \mathrm{S}, 144^{\circ} 00^{\prime} \mathrm{E}$, Hill 31, 6.1968 (BRI); "Bundoran", near Nonda between Hughenden and Cloncurry, Hubbard \& Winders 7277, 2.1931 (BR.I)*; "Afton Downs", 20 miles [32 km] SW. of Hughenden, Everist 3061, 6.1947 (BRI). Gregory North: near McKinley, per Mahoney 6.1953 (BRI); "Headingly", c. 30 miles [c. $48 \mathrm{~km}$ ] N. of Urandangie, Everist 3305, 12.1947 (BRI); "Elderslie", Winton, Kennedy 25, 9.1935 (BRI); Winton-Boulia road, 52 miles [84 km] from Winton, Gittins 674, 4.1963 (BRI); Winton, Lee NSW 45868, 11.1949 (NSW); 30 miles [48 km] SE. of Winton, Trapnell 169, 7.1958 (BRI); "Roxborough Downs", Bailey 12.1895 (BRI); between Glenormiston and Toko Ranges, Boyle 1-2.1935 (BRI); Boulia-Bedourie road c. 20 miles [c. $32 \mathrm{~km}$ ] S. of Boulia, per Mahoney 6.1953 (BRI). Mitchell: HughendenMuttaburra road near "Kentle Downs", $21^{\circ} 30^{\prime} \mathrm{S}, 144^{\circ} 00^{\prime}$ E, Hill 6.1968 (BRI)*; "Tiree" Station, c. 68 miles [c. $110 \mathrm{~km}$ ] S. of Torrens Creek, Ford NSW 45853, 9.1949 (NSW)*; Darr R, de Burgh Birch (BRI)†; Isisford road on cleared gidyea . . ., Purcell 4.1962 (BRI)†; Reserve, Barcaldine road, 10 miles [16 km] from Blackall, Cull 2.1962 (BRI) $\dagger$; "Mineeda" near Blackall, Everist 1247, 8.1935 (BRI)†; "Mineeda" Station near Blackall, Everist \& Smith 243, 2.1937 $(\mathrm{BRI}) \dagger$.

Northern Territory: Barkly Tableland: 1 mile $[1.6 \mathrm{~km}]$ E. of No. 7 Bore, near Elliott, Latz 437, 2.1969 (BRI); 12 miles [19 km] SE. of "Creswell Downs" homestead, Chippendale NT $5581,3.1959$ (NSW); 7.7 miles [12 km] S. of Monkaderry Waterhole, "Banka Banka", Chippendale NT 7037, 6.1960 (NSW); Bishops Bore, 17 miles [27 km] NW. of "Brunette Downs" homestead, Chippendale NT 5011, 10.1958 (PERTH); Bore No. 51, "Brunette Downs NT.", Nicholls 798, 5.1968 (BRI); 7 miles [11 km] N. of "Brunchilly", Chippendale NT 7063, 6.1960 (NSW); 15 miles [24 km] E. of "Brunchilly", Chippendale NT 7092, 6.1960 (NSW); 2.6 miles [4 km] SE. of Ranken [store], Chippendale NT 7199, 6.1960 (NSW); 23 miles [37 km] W. of Camooweal, Chippendale NT 1485, 8.1955 (BRI); 0.6 miles $[1 \mathrm{~km}] \mathrm{E}$. of "Soudan" Station, Perry 680, 4.1948 (BRI); 3 miles [5 km] SSE. of "Soudan", Nicholls 876, 6.1968 (BRI). Central Australia: 30 miles [48 km] SW. of "Tobermorey" homestead, Chippendale NT 393, 9.1954 (NSW, BRI); Macdonnell Range, lat. $18^{\circ} 30^{\prime}$ [? McDouall Range], Macd. Stuart (MEL, NSW).

Western Australia: Northern Province-Ord: 40 miles [64 km] N. of "Sturt Creek" Station, Beard 5627, 6.1968 (PERTH).

1 iii C. eremaea F. Muell., Enum. PI. coll. A. C. Gregory in Votes \& Proc. New South Wales Legisl. Assemb., 2.v.1859 (Papers relative to Expedition in search of Dr Leichhardt); F. Mueller, Fragm. 3: 56 (1862).-C. dissitiflora var. eremaea (F. Muell.) Benth., Fl. Austral. 2: 184 (1864); F. Mueller, Fragm. 9: 157 (1875); Moore \& Betche, Handb. Fl. New South Wales: 145 (1893); F. M. Bailey, Queensland F1. 2: 376 (1900); Maiden \& Betche, Census New South Wales P1.: 106 (1916). HolotyPe: Coopers R [Queensland/South Australia], A. C. Gregory (MEL 1010369, "seen by Bentham"; the date of collection [6.1858] has been added by J. H. Willis).

* Flowers larger than usual and perhaps approaching C. benthamiana.

$\dagger$ ? intergrade between subspecies. 
See also under the subspecies for synonymy.

[C. dissitiflora sensu auctt., non Benth.: Black, Fl. South Australia 2: 306 (1924), and ed. 2, 2:448 (1948); here C. eremaea and $C$. strehlowii are regarded as synonyms of $C$. dissitiflora; Eichler, Suppl. Black's Fl. S. Australia: 186 (1965)].

Soft-wooded shrubs, densely tomentose to completely glabrous, erect-growing to about $1 \mathrm{~m}$ high, the individuals apparently seed-derived but probably more often regenerated from underground parts (histologically, roots) which appear to be extensive and horizontal, rather than congested and ascending as in $C$. dissitiflora. Leaves unifoliolate, or if trifoliolate the lateral leaflets often much reduced or at most half the length of the terminal. Leaflets oblong, elliptical, ovate, trullate or obovate (mostly SAC 13-14, 36-37, 56-57), of thicker texture than in C. dissitiflora as shown by wrinkling in dried specimens, rarely showing the minute dotting of the surfaces characteristic of that species, glabrous in extreme forms of subsp. strehlowii to densely tomentose in those of subsp. eremaea, the hairs appressed to spreading, silvery or grey, but cream, fawn or occasionally golden brown in longdried material; petioles in subsp. eremaea often persisting after the lamina has fallen. Stipules absent or extremely small (less than $1 \mathrm{~mm}$ long), very rarely larger (to $4 \mathrm{~mm}$ long) and spreading like those of $C$. dissitiflora. Inflorescences terminal on stems and branches, racemes usually of c. 15-30 flowers. Flowers variable in size and form, pedicellate and bracteate. Calyx open-campanulate with five subequal teeth, usually pubescent, densely or less so corresponding with the vegetative parts, the teeth triangular, the tube of about equal length and narrowed into a short receptacle with a pair of small bracteoles attached at or near the top of the pedicel. Standard nearly circular (SAC 6-7) but almost always slightly broader than long, the auricles scarcely developed, the claw rather broad. Wings more or less obtriangular (SAC 86-87), the claw upcurved. Keel varying from the short, "round" form through indeterminate specimens to the long, "straight" form (Figs. 1, 2), the former probably more common; beak slightly incurved in the "round" flowers to scarcely upturned in the "straight" form. Ovary and pod hoary to pubescent, in the young stages with the hairs along the upper suture longer and denser but not significantly so in the fruit; pod oblong-clavate, tapered asymmetrically into the stipe. Seeds chrome yellow with a faintly dimpled surface, the radicular lobe not prominently hooked.

Terminal leaflet (10-) 25-40 (-80) mm long, (2-) 5-15 (-26) $\mathrm{mm}$ broad, the laterals usually less than $1 \mathrm{~cm}$ long; stipules usually absent, or less than $1.5 \mathrm{~mm}$, rarely more. Flowers rarely less than $10 \mathrm{~mm}$ long, often $12-15 \mathrm{~mm}$, occasionally to $18 \mathrm{~mm}$; pedicel often $3-5 \mathrm{~mm}$; bract narrow, $1.5-4 \mathrm{~mm}$. Calyx teeth (1.5-) 2-3 (-4) $\mathrm{mm}$ long, tube about equal, receptacle 1-1.5 mm; bracteoles $(0.5-) 1.5-2(-3) \mathrm{mm}$ long. Standard (8-) 10-11 (-14) mm long, (9-) 10-12 (-14) mm broad, claw (2.5-) 3-4 mm long. Wings (8-) 9-10 (-11) mm long, claw mostly 2-3 mm. Keel (8-) 11-12 (rarely -18) $\mathrm{mm}$ long, (4)- 4.5-5.5 (-7) $\mathrm{mm}$ broad, claw 2-3 (-4) $\mathrm{mm}$, beak 8-10 (rarely -14) mm long. Pod c. 2-3 cm long, 3-7 mm diam., stipe $3-4 \mathrm{~mm}$. Seeds 4-5 $\mathrm{mm}$ long, c. $3 \mathrm{~mm}$ broad.

Distribution (see Map 1): In sandy soils of Central Australia, extending into eremean parts of all the adjoining States, subsp. eremaea in the eastern and subsp. strehlowii in the central and western parts of the specific range. 


\section{A species of two races, the subspecies below:}

1. Leaflets essentially oblong, 1 or 3 , the laterals if present reduced and sometimes very small or, if approaching the terminal in form, very rarely more than half its length, not noticeably thick except sometimes by virtue of the tomentum, the leaf surface where visible through the hairs often with fine multidirectional wrinkling or pitting when dried, densely to sparsely pubescent but always with some hairs on the upper surface, the hairs appressed to spreading and usually denser below than above; stipules absent or less than $1 \mathrm{~mm}$ long, occasionally obvious, rarely to $4 \mathrm{~mm}$, and often obscured by the pubescence; flowers variable in form, from small and "round" to larger and

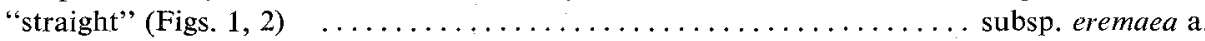

1. Leaflets essentially ovate to trullate, commonly 1 , or 3 with the laterals usually small, often circular to occasionally ovate-oblong (perhaps more fully developed and close to those of $C$. dissitiflora in some Western Australian plants); thickish in texture and drying with a wrinkled surface, quite glabrous above or rarely with a very sparse scattering of hairs on young leaves, the lower surface usually with a more or less sparse pubescence, or quite glabrous; hairs short, appressed, or occasionally (seen only in a few collections from Central Australia) sparse and stiffly spreading; stipules usually absent, rarely present and up to $1.5 \mathrm{~mm}$ long; flowers often large and "straight" but grading to the small "round" form particularly in the southwestern part of the range

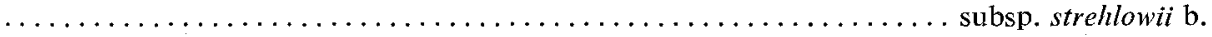

\section{1 iii a subsp. eremaea.}

Pentadynamis incana R. Br. in Bot. App. in Sturt, Narr. Exped. Centr. Australia 2: 76 (1848), non Crotalaria incana L., Sp. Pl.: 716 (1753). HolotyPe, n.v.: "on sand-hills with Crotalaria sturtii, D. Sturt". Sturt recorded C. sturtii (i.e. C. cunninghamii) as "on top of the ridges in pure sand, from S. 1at. $28^{\circ}$ to $26^{\circ}$ ", and his route crossed these latitudes in the vicinity of the Warburton R. The Type of $P$. incana would therefore have come from the Simpson Desert somewhere between the Warburton and Coopers Creek, in South Australia, c. $139^{\circ}$ E long.

[C. dissitiflora sensu auctt., non Benth.: ? Tate, Fl. Extratrop. South Australia: 66, 223 (1890). Tate's description implies subsp. eremaea, but the localities cited and Tate's later (1896) usage suggest that his references applied to subsp. strehlowii q.v. and intergradant forms as well as to subsp. eremaea].

[C. dissitiflora var. eremaea sensu auctt., non Benth. sensu str.: Moore \& Betche (1893); Bailey (1900); Maiden \& Betche (1916); in references above in the synonymy of $C$. eremaea. These authors there used this equivalent of $C$. eremaea for that part of $C$. eremaea occurring in the area they treated, viz. subsp. eremaea, an interpretation supported by the descriptions given].

\section{Characters as given in the key.}

Distributron: In the eastern and particularly southeastern parts of the specific range, i.e. in southwestern Queensland, northwestern New South Wales, northeastern South Australia and southeastern Northern Territory; nearly always in sandy soils and chiefly in the sandy expanses of the Simpson Desert and its extensions into semi-desert regions, showing various combinations of characters with typical subsp. strehlowii (see below) northwards from Spencers Gulf, and appearing occasionally with its own characteristic features within the area occupied by that subspecies; occasionally also on red and brown loams in northwestern New South Wales and Queensland.

Specimens Examined: Queensland: Gregory North: Glenormiston, No. 20 Bore, Colliver 8.1949 (BRI); between Glenormiston and the Toko Ranges, Boyle 1-2.1935 (BRI 126554); Boulia-Bedourie road, 20 miles [32 km] N. of Bedourie, Johnson 73/134, 9.1973 (NSW)*; Bedourie-Birdsville road, 32 miles [51 km] S. of Bedourie, Johnson 73/137, 9.1973 (NSW). Gregory South: Jundah to border, Cooper R, Sherman 8.1946 (BRI); "Retreat", on low sandhill, Everist 6321, 9.1960 (BRI); Bedourie-Birdsville road, 50 miles [80 km] N. of Birdsville, Johnson 73/139, 9.1973 (NSW)*; "Mooraberree", Everist 4098, 9.1949 (BRI); 36 miles [58 km] ENE. of Birdsville on Bedourie road, $25^{\circ} 36^{\prime} \mathrm{S}, 139^{\circ} 45^{\prime} \mathrm{E}$, Briggs 4586, 5.1972 (NSW); 46 miles [74 km] E. of Birdsville on Betoota road, Rodd NSW 113675, 8.1964 (NSW); 20 miles [32 km] from

* C. eremaea (?-C. dissitiflora). See p. 323 . 
"Roseberth" Station towards Birdsville... Johnson 33, 6.1972 (NSW); Simpson Desert, widespread on sandhills, Cockburn BPS 40, 7-8.1969 (BRI); Poeppel Corner, $26^{\circ} \mathrm{S}, 138^{\circ} \mathrm{E}$, Boyland 270, 9.1966 (BRI, K); "Ingella", c. 20 miles [c. $32 \mathrm{~km}$ ] SE. of Windorah, Everist 4045, 6.1949 (BRI, K); Quilpie (but noted as coll. on red sandhill), Smith 11.1954 (BRI); "Thylungra", c. 75 miles [c. $121 \mathrm{~km}$ ] NW. of Quilpie, Everist $5742,10.1955(\mathrm{BRI}, \mathrm{K}) ; 80$ miles [129 km] W. [NW.] of Quilpie, Stranger 8, 3.1959 (BRI), Everist 6284, 9.1960 (BRI); "Copai", 55 miles [89 km] NW. of Quilpie, Mackay 8.1961 (BRI); "Nappamerrie" Station, Cooper Creek, Jackson 445, 8.1962 (AD); 26 mile tank-NE. "Nappamerry", Wilson 9.1961 (BRI); between Innamincka S.A. and "Nappamerry" Q., Marks 8.1967 (BRI); c. 10 miles [c. 16 km] NE. of "Nockatunga", Carolin 4150, 8.1969 (SYD); red sand dunes 80 miles [129 km] W. of Thargomindah, Cockburn $47,9.1963$ (BRI).

New South Wales: Far Western Plains: Queensland border, N. and a little W. of Broken Hill, MacGillivray NSW 45874, 4.1917 (NSW); Fort Grey, Brough \& Beadle 8.1939 (SYD); near Fort Grey, Brough \& Beadle 8.1939 (SYD); "Olive Downs" c. NNW. of Tibooburra, Milthorpe 880, 10.1972 (NSW); "Waka", c. between Fort Grey and Tibooburra, Milthorpe 882, 10.1972 (NSW); Bindara Tank, "Delalah Downs", Cunningham SCS 495, 8.1972 (NSW); $29^{\circ} 22^{\prime} \mathrm{S}, 143^{\circ} 03^{\prime} \mathrm{E}$, "Delalah Downs", Pickard 2071, 3.1973 (NSW); "Gumvale" c. $25 \mathrm{~km}$ W. by S. of Tibooburra, Johncock NSW 101222, 101223, 4.1967 (NSW); Tibooburra, Burgess \& Beadle 2.1950 (SYD); "Yandama" Station, Collier NSW 45857, 7.1910 (NSW); Milparinka, Whalley NSW 45849, 4.1957 (NSW), Beadle 10.1939 (SYD); "Winnathee" 60 miles [97 km] W. of Milparinka, Johnson \& Constable NSW 33370, 6.1955 (NSW, K); Clifton Bore, E. of Milparinka, Blaxell 416, $4.1970(\mathrm{NSW})$; Broken Hill +138 miles [222 km] towards Tibooburra, Gittins 1910, 8.1969 (BRI, NSW); 20 miles [32 km] S. of Milparinka, Beadle NSW 113679, 5.1963 (NSW); Lake Yantara, Beadle 8.1941 (SYD); Silver City Highway, close to Salt Lake, Martensz 246, 12.1969 (NSW); "Callindry" Station, Leigh W205, 7.1968 (NSW); Cobham Lake, Bäuerlen NSW 45866, 9.1887 (NSW), Williams NSW 4587I, 10.1901 (NSW); "Cobham", MacGillivray per Morris 669, 8.1921 (NSW); sandhills, "Cobham", Morris 784, 10.1921 (NSW, BRI); Paldrumatta Bore, Corbett NSW 45869, 4.1900 (NSW); $3.2 \mathrm{~km} \mathrm{~N}$. of Turleys Gate, S.A.-N.S.W. border, Campbell \& Pickard 1256, 11.1970 (NSW); $180 \mathrm{~km} \mathrm{~N}$. of Broken Hill, Mulham W771, 8.1974 (NSW); $35 \mathrm{~km} \mathrm{~N}$. of Broughams Gate . . 30 35' S, $141^{\circ} 00^{\prime} \mathrm{E}$, Lee 226, 9.1971 (NSW); $0.8 \mathrm{~km} \mathrm{S.} \mathrm{of} \mathrm{"Tielta"} \mathrm{homestead} \mathrm{.} \mathrm{.} \mathrm{.} \mathrm{30} 50^{\circ}$ ' S, 141 ${ }^{\circ} 14^{\prime} \mathrm{E}$, Lee 216, 9.1971 (NSW); Sandhills, Barrier Range, Collins 9.1921 (SYD); Kinchega National Park, Menindee, Ryan \& Everley NSW 113672, 6.1959 (NSW).

South Australia: Far North: South of Charlotte Waters, Kempe NSW 45872, 9.1883 (NSW); Outer Birdsville Track, 35 miles [56 km] ex Birdsville, Johnson 73/140, 9.1973 (NSW); Walkers Well [prob. vicinity "Cordillo Downs"], Basedow 51, 10.1919 (NSW, K)*; Bradys Waterhole near Cordillo Downs, Basedow 61, 10.1919 (NSW); Outer Birdsville Track, 48 miles [77 km] S. of "Clifton Hills", Johnson 73/141, 9.1973 (NSW); Seven-mile Creek, S. of Goyders Lagoon, Crocker 6, 7.1939 (AD); Innamincka, Herb. Tate 391, 6.1884 (AD); Lake Eyre, c. $50 \mathrm{~km} \mathrm{NW}$. of Marree, Hill 213, 7.1955 (AD); Birdsville Track, 95 miles [153 km] N. of Marree, Johnson 73/144, 9. 1973 (NSW); "Killalpaninna" (Mission Station), Coopers Creek near Lake Eyre, Howitt NSW 45854, 12.1883 (NSW); Natarranni sandhills, Birdsville Track 85 miles [137 km] from Marree, Johnson 21, 6.1972 (NSW); near Cannawulicaninna Bore, Birdsville Track, c. $110 \mathrm{~km} \mathrm{NE}$. of Marree, Crisp \& Noble 18, 4.1969 (AD); $108 \mathrm{~km} \mathrm{~N}$. of Marree, Milthorpe 3044, 10.1974 (NSW); Birdsville Track, 7 miles [11 km] c. N. of Marree, Johnson 73/146, 9.1973 (NSW); Mt Lyndhurst, Koch 541, 10.1900 (NSW). North Lake Torrens Basin: Red Lake c. $130 \mathrm{~km}$ WSW. of Marree, Aitken 12.1964 (AD); "Mulgaria" homestead, 30 $14^{\circ} \mathrm{S}$, $137^{\circ} 38^{\prime}$ E, Aitken 12.1964 (AD). Lake Torrens Basin: c. 26 miles [42 km] N. of Andamooka, Macfarlane 6.1964 (AD); Andamooka, sandhills, Williams 2812, 6.1966 (AD); Andamooka Opal Fields near landing strip, Weber 1378, 9.1968 (AD, K); c. $30 \mathrm{~km}$ due N. of Woocalla and c. $7 \mathrm{~km}$ E. of Mt Gunson, Lorinczi \& Tonkin Type D no. 1, 9.1966 (AD).

Northern Territory: Central Australia: 7 miles [11 km] NW. of "Numagalong" Station homestead, Nelson \& Swinbourne NT 11801, 8.1965 (NSW); Sandy Valley, Wycliffe Creek, Allen 598, 7.1922 (NSW); Alice Springs, Tate 1894 (AD); "Andado" to Georgina R, CrockerSimpson Desert Expedition 1939 (AD).

* C eremaea (?-C. dissitiflora). See p. 323. 
The following specimens may be included in subsp. eremaea (see Map 1, subsp. eremaea atypical) though the diagnostic characters are less clearly shown, having less dense to sparse pubescence though still with some hairs on the upper surface of the normally oblong leaflets, or the tomentose leaflets tending to ovate shapes though often narrower than in subsp. strehlowii and about 5-10 mm wide.

QueEnsLand: Gregory North: 13 miles [21 km] from Diamantina Shire boundary-Bedourie road on "Monkira" Station, Williams 153, 10.1968 (BRI). Mitchell: 48 miles [77 km] W. of Yaraka, Everist 7363, 8.1963 (BRI). Gregory South: sandhills about Georgina, Simpson Desert Expedition Camp 21, Crocker 5, 7.1939 (AD); 10 miles [16 km] from Windorah towards "Currawilla" Station, c. $25^{\circ} 21^{\prime} \mathrm{S}, 142^{\circ} 28^{\prime}$ E, Gittins $1938,8.1969$ (BRI, NSW); 17 miles [27 km] W. of Windorah, Everist 1555, 6.1937 (BRI); 45 miles $[73 \mathrm{~km}] \mathrm{S}$. of W'indorah, Everist 4044, 6.1949 (BRI); 27.7 miles [c. $44 \mathrm{~km}$ ] NW. of Tenham Bore, Trapnell E52, 6.1969 (BRI); sandhill at outlet of Eulbertie Waterhole, Coopers Creek, Ogilvie 8.1961 (BRI); 50 miles [81 km] W. of Quilpie, 5 miles [8 km] N. of the Quilpie to Eromanga road . . "Kyra" homestead, Emmerson 8.1965 (BRI); "Nockatunga" Station, Carolin 4239, 8.1964 (SYD); SW. Queensland, Little 1910 (BRI).

South Australia: Far North: 38 miles [c. $61 \mathrm{~km}$ ] E. of Dalhousie Springs, Lothian 1432, 8.1963 (AD); also a series of other specimens from around this locality, Lothian 1487, 1622, 1657, 1702, 1796, 1807, all 8.1963 (AD; 1796 also at NSW). Woomera: "Purple Downs", Weber 1541, 9.1968 (AD). Lake Torrens Basin: Yeltacowie, Murray 33, 6.1927 (AD, bis); Arcoona, Murray 33 (sic), 8.1927 (AD).

Northern Territory: Central Australia: 17 miles [27 km] SE. of Bottom Bore, Hale R, Chippendale NT 4938, 9.1958 (AD, NSW, PERTH); Simpson Desert, $25^{\circ} 15^{\prime} \mathrm{S}, 136^{\circ} 43^{\prime} \mathrm{E}$, Symon 4379, 11.1966 (AD).

As well as the specimens cited above, there were many in AD which I examined in 1971, determinable then as $C$. eremaea. Not having re-examined them and realizing the possibility of concept changes over the intervening period, they are not cited here, but their distribution is in agreement with that shown in Map 1.

The following specimens do not fall clearly into either of the subspecies (see Map 1, intergrades); nearly all occur in a zone between the main populations of the races, but they represent a number of combinations of the different subspecific characters, rather than a clinal intermediate series, though a near-clinal change is probably seen in South Australia. The commonest combination of subspecific characters is the leaflet shape of one subspecies with the pubescence of the other, e.g. the leaflet may be clearly oblong as in subsp. eremaea, but glabrous above and wrinkled as in subsp. strehlowii; or the leaflet shape may be rather indefinite or narrow-ovate, as in those plants of subsp. strehlowii with narrow leaflets, but this is combined with some, albeit sparse, pubescence on the upper surface of the leaflet. The nature of the pubescence also varies, and a few of these plants have a sparse but rather stiff and spreading pubescence which is not seen in either of the 'pure' subspecies and suggests a reduction in density of hairs of some of the densely tomentose forms of subsp. eremaea found in the Simpson Desert:-

Northern Territory: Central Australia: c. 15 miles [c. $24 \mathrm{~km}$ ] S. of Wycliffe Well (c. 220 miles [c. $353 \mathrm{~km}$ ] N. of Alice Springs), Everist 4279, 1.1950 (BRI); c. $55 \mathrm{~km} \mathrm{~N}$. of Barrow Creek, v. Dam 52, 6.1969 (AD); Elkedra R, 15.2 miles [c. 24 km] E. of "Elkedra" homestead, Chippendale $N T$ 3126, 10.1956 (NSW); 5 miles [8 km] SW. of "Tarlton Downs", Winkworth 594, 10.1954 (PERTH); creek $64 \mathrm{~km} \mathrm{~N}$. of Arltunga, Cleland 9.1930 (AD); 4.2 miles [c. $6.5 \mathrm{~km}$ ] E. of Allua Well, Ross R, Chippendale NT 4965, 9.1958 (NSW); 70 miles [113 km] SE. of "Ringwood", Winkworth 1273, 9.1955 (BRI, NSW, PERTH); 37 mile peg S. of Alice Springs, Carolin 5153, 8.1965 (SYD); Window Hill, Simpson Desert, Chippendale NT 1607, 9.1955 (AD, BRI, NSW). 
1 iii b subsp. strehlowii (Pritzel) A. Lee stat. nov.-C. strehlowii Pritzel in Feddes Repert. 15: 356 (1918); Eichler, Suppl. Fl. South Australia: 186 (1965); Polhill in Kew Bull. 22: 247 (1968); Chippendale in Proc. Linn. Soc. New South Wales 96: 239 (1972). HolotyPE: n.v., believed destroyed in B: Hermannsburg on the Finke R [Northern Territory-Central Australia], Strehlow 5, 1906-8. The description leaves little doubt of identity, and I here designate the following topotypic specimen as NeOTYPE: $16 \mathrm{~km} \mathrm{W.} \mathrm{of} \mathrm{Hermannsburg} \mathrm{on} \mathrm{the} \mathrm{Areyonga} \mathrm{road,} \mathrm{Latz} \mathrm{389,} 12.1968$ (NSW).

[C. dissitiflora Benth. var. eremaea sensu auct., non Benth. sensu str.: Tate in Part III (Section II, Botany): 152 (1896) in Spencer, ed., Rep. Horn Exped. Centr. Australia. Tate here used this synonym of $C$. eremaea for that part of $C$. eremaea occurring in the habitat and localities cited, i.e. for subsp. strehlowii].

[C. dissitiflora sensu auctt., non Benth. sensu str.: Ewart \& Davies, Fl. N. Territory: 141 (1917) in part, viz. "Glabrous form . . ."; Gardner, Enum. P1. Austral. Occ.: 62 (1930); Beard, ed., (Descr. Cat.) W. Austral. Pl. ed. 2: 65 (1970). These authors here used this binomial for that part of the dissitiflora complex occurring in the habitat and localities cited, i.e. for C. eremaea subsp. strehlowii. Gardner's usage is implicit in his listing also C. benthamiana; Beard later, in Wildfl. Northwest: 9, 28 (c. 1972) used C. dissitiflora for C. benthamiana, regarding the Fortescue taxon referred to as a part of C. dissitiflora].

Characters as given in the key, differing from subsp. eremaea in its leaf form and pubescence, the leaflets often single, trullate or ovate, and glabrous or nearly so; the correlation between these characters, however, is by no means perfect though it applies in the majority of specimens; its breakdown produces the "intermediate" specimens showing associations of characters different from the usual.

Distribution (see Map 1): Northwest of South Australia, eremean Western Australia and Northern Territory (Central Australia), i.e. in the western and northwestern part of the specific range, and showing combination with the Type subspecies chiefly along the line of junction in South Australia, northwards from Spencers Gulf, and in Central Australia: often on sandhills but also on sandplains and sandy soils near watercourses.

Specimens Examined: South Australia: Far North: 20 miles $[32 \mathrm{~km}$ ] S. of Ernabella, Turvey NSW 113664, 4.1964 (NSW); 40 miles $[64 \mathrm{~km}]$ N. of Oodnadatta, Lothian 1400, 8.1963 (NSW); $50 \mathrm{~km} \mathrm{~N}$. of Oodnadatta, Milthorpe 3058, 10.1974 (NSW); Alberga R, Sheaffe NSW

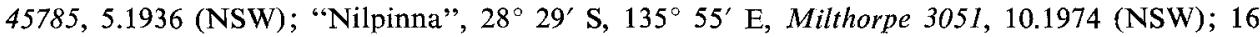
miles [26 km] SE. of Emu, Forde 449, 8.1956 (PERTH).

Western Australia: Eremean Province-Carnegie: 3 miles [5 km] NE. of Walter James Range, N. of Rawlinson Range, George 8344, 10.1966 (PERTH); 69 miles [111 km] SE. of Giles Weather Station on Gunbarrel Highway, Johnson 73/4, 6.1973 (NSW); \pm 100 miles [c. $161 \mathrm{~km}$ ] E. of Warburton Mission, George 5283, 7.1963 (PERTH); Lake Carnegie, Fairall 2097, 7.1966 $($ PERTH)* 38 miles [61 km] SE. of Warburton, George 2938, 8.1961 (PERTH); 36 miles [58 km] SE. of Warburton, George 3898, 8.1962 (PERTH); E. of Laverton, Geol. Survey 1916 (PERTH).

Northern Territory: Central Australia: Tanami Track, 107 miles [172 km] SE. of Rabbit Flat, Johnson 73/61, 6.1973 (NSW); near Ti Tree Creek, N. of Alice Springs, Hutton NSW 98221, 5.1967 (NSW); Boomerang Waterhole, Lander R, 42 miles [63 km] NW. of "Willowra" homestead, Chippendale NT 4733, 7.1958 (AD, NSW); 40 miles [64 km] N. of Barrow Creek, Stuart H'way [21 ${ }^{\circ} 04^{\prime} \mathrm{S}, 134^{\circ} 10^{\prime} \mathrm{E}$, . Must 168, 7.1968 (NSW); Hanson R-Anningie turnoff, Parker 112, 7.1969 (NSW); 9.3 miles [15 km] W. of "Amaroo", Chippendale NT 2528, 8.1956 (NSW); 3.7 miles [6 km] SE. of Yuendumu, Chippendale NT 4191, 4.1958 (PERTH); "Gibeanie" Station [now abandoned], 125 miles [200 km] N. of Alice Springs, Rose 349 SN 52/244 (S)

* A trifoliolate plant occurring a vast distance further west than any similar collection; the lateral leaflets are less than half as long as the terminal but scarcely modified in shape. 
(BRI); 5 miles [8 km] NW. of "Aileron", Nelson 386, 8.1962 (NSW); Carinya Bore, "Central Mount Wedge" Station, McKee 8579, 2.1961 (NSW); 13 miles [21 km] E. of "Alcoota" Station, Perry 3393, 3.1953 (BRI); Narwietooma, Gardner 11578, 3.1953 (PERTH, MEL [as C. arida ined.]); Ehrenberg Range, 60 miles [97 km] E. of Sandy Blight Junction, Butler 65, 5.1967 (PERTH); 32 miles [51 km] NW. of "Hamilton Downs", Winkworth 361, 6.1954 (BRI); Northwest Stock Route, c. 6 miles [c. $10 \mathrm{~km}$ ] NW. of Desert Bore, Everist 4173, 1.1950 (BRI); 2 miles [3 km] W. of No. 2 Desert Bore, "Hamilton Downs", Chippendale NT 1685, 9.1955 (NSW); in steppes near Arltunga, Gauba CBG 001355, 9.1950 (NSW, bis); Alice Springs, Animal Industry Branch 381 (PERTH); Alice Springs district, Gardner (PERTH); Standley Chasm, 40 miles [64 km] W. of Alice Springs, Dale NSW 45784, 7.1939 (NSW); 9 miles [15 km] SE. of Alice Springs, Nelson 137, 12.1961 (NSW); 19 miles [30 km] S. of Alice Springs, Swinbourne 399, 8.1962 (PERTH); Deep Well road, 19 miles [30 km] S. of Alice Springs, Nelson NT 11980, 5.1966 (AD, NSW); 20 miles [32 km] S. of Alice Springs on Deep Well road, Cunningham \& Mulham 2045, 3.1974 (NSW); 33 miles [53 km] SW. of Alice Springs, Chippendale NT 492, 11.1954 (AD); Palm Valley, George 5002, 7.1963 (PERTH); Illara Creek, 4.5 miles [7 km] NW. of "Tempe Downs", Chippendale NT 7400, 10.1960 (NSW); 29 miles [47 km] E. of "Tempe Downs" homestead, Chippendale NT 572, 11.1954 (BRI, NSW, PERTH); Finke R, Stuart Highway, George 5049, 7.1963 (PERTH); Finke R at Henbury bridge, Briggs 3500, 6.1970 (NSW); Lake Amadeus, $24^{\circ} 57^{\prime} \mathrm{S}, 131^{\circ} 12^{\prime} \mathrm{E}$, Latz 5713, 9.1974 (NSW); between Shaw and Docker Rivers, Carolin 5389, 8.1966 (SYD); Irving Creek, N. of Petermann Ranges, Nelson 942, 3.1964 (AD, NSW); 3 miles [ $5 \mathrm{~km}$ ] W. of Lasseters Cave, Petermann Ranges, Maconochie 692, 1.1969 (NSW); c. 17 miles [c. $27 \mathrm{~km}$ ] NW. of "Andado" homestead, Must 88, 7.1968 (BRI); 75 miles [121 km] E. of Ayers Rock, Jancey 5.1963 (SYD); Ayers Rock, Woolnough \& Johnson NSW 113665, 8.1968 (NSW); Simpson Desert, 46 miles [74 km] SW. of "Andado" homestead, Chippendale NT 6608, 9.1959 (NSW, AD); Simpson Desert, 25 $47^{\prime}$ S, $125^{\circ} 15^{\prime}$ E, Mitchell 99, 8.1974 (NT, NSW).

In addition, the following may be included in subsp. strehlowii (see Map 1, subsp. strehlowii atypical) though the diagnostic characters are less definite; this is shown chiefly in the development of leaflets usually narrower than in typical subsp. strehlowii and tending, sometimes strongly, to the oblong shape seen in subsp. eremaea, these shapes being combined with the glabrous or near glabrous and usually wrinkled surface of subsp. strehlowii, and sometimes in trifoliolate leaves:

South Australia: Far North: "Macumba" Station, Ising 11.1950 (AD). Lake Torrens Basin: 8 miles [13 km] N. of "Parakylia", Filson 3251, 9.1960 (AD). Lake Torrens Plateau: c. $3 \mathrm{~km} \mathrm{~N}$. of South Gap, Weber 1215, 9.1968 (AD). ? loc.: Alice Springs to Marree, Ward 8.1947 (SYD).

Northern Territory: Central Australia: 42 miles [63 km] NE. of Barrow Creek, Winkworth 957, 3.1955 (BRI, PERTH); 61 miles [98 km] from Jervois Mine towards Plenty R, Gittins 1983, 9.1969 (BRI, NSW); Benstead Creek, 32 miles [51 km] ENE. of Alice Springs, Forde 86, 2.1956 (NSW); 2.5 miles [4 km] E. of Atherrita Bore, "Todd R" Station, Nelson 1343, 8.1964 (NSW); Finke R valley (south of Alice Springs), Hutton NSW 98220, 5.1967 (NSW).

For other specimens of this species which do not fall clearly into either of the subspecies but show atypical combinations of their characters, see under subsp. eremaea, p. 337.

As with subsp. eremaea I examined, and determined as $C$. strehlowii, a number of specimens at AD in 1971, in addition to those cited here for subsp. strehlowii; they are similarly excluded from Map 1 but again support the distributions shown there.

\section{C. MITCHELLII AND C. SMITHIANA}

C. mitchellii, based on Mitchell's collection from near a lagoon on the Balonne $\mathrm{R}$, Queensland, had at first a limited circumscription equivalent to that of the Type 
subspecies distinguished below. Later Bentham enlarged it by including specimens of a smaller-leaved, less pubescent variant, the southwestern race, among his citations in Flora Australiensis; this is formally distinguished as subsp. laevis below. Still later Ewart described a Central Australian plant as C. mitchellii var. tomentosa, but the taxon based on Ewart's Type, while superficially similar in its flowers to C. mitchellii, is distinct in its vegetative parts (see Table 2) and comprises a taxon of eremean occurrence quite disjunct from that of $C$. mitchellii, which is coastal in Queensland and penetrates inland scarcely beyond the western slopes divisions of New South Wales. It is described below as C. smithiana.

TABLE 2

DIFFERENCES BETWEEN C. MITCHELLII AND C. SMITHIANA

\begin{tabular}{|c|c|c|}
\hline & C. mitchellii & C. smithiana \\
\hline Leaves & 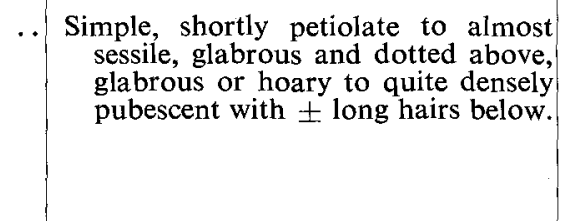 & $\begin{array}{l}\text { Unifoliolate, the leaflet shortly } \\
\text { petiolulate and articulate on a } \\
\text { longer petiole, the joint sometimes } \\
\text { obscure in the pubescence, tomen- } \\
\text { tose on both sides at first, later } \\
\text { more sparsely hairy to glabrous } \\
\text { above. }\end{array}$ \\
\hline Stems & .. $\begin{array}{c}\text { Erect, branched, glabrous or with } \\
\text { short upturned hairs. }\end{array}$ & $\begin{array}{l} \pm \text { prostrate after the first, forming a } \\
\text { cushion-like growth, densely } \\
\text { spreading-pubescent with the hairs } \\
\text { later usually downturned. }\end{array}$ \\
\hline Stipules & Soon caducous. & Persistent. \\
\hline
\end{tabular}

2 i C. mitchellii Benth. in Mitch. Trop. Australia: 122 (1848); Bentham, Fl. Austral. 2: 181 (1864); F. Mueller, Fragm. 9: 156 (1875), in part; F. M. Bailey, Queensland F1. 2: 374 (1900); Moore \& Betche, Handb. Fl. New South Wales: 145 (1893); Domin in Biblioth. Bot. $22\left(89^{2}\right)$ : 733 (1925) excl. var. tomentosa and occurrence in South Australia. HoLOTYPE: bed of Baloon [Baloone] R [QueenslandMaranoa], Mitchell, 10 April 1846, photograph only seen: (K, print at NSW of CSIRO Neg. No. Kew 1112). Two specimens marked * in the citations below were matched with the Type by L. Pedley.

[In references under $C$. mitchellii, other than those above, the name has often been used with some degree of misapplication, either by misdetermination or by changes in circumscription, as follows: by F. Mueller (1862) when describing C. novae-hollandiae q.v.; by Tate (1890), Black (1924, 1948), Chippendale \& Murray (1958), the Poison Plants Comm., CSIR (1934), Beard (1970), and probably Gardner (1930), when referring in part or in various ways to $C$. smithiana q.v.].

Soft-wooded erect or decumbent shrubs about $0.5-1 \mathrm{~m}$ in height with glabrous or pubescent stems, the hairs rather short and ascending, and simple leaves. Leaves often elliptical or narrow-elliptical, glabrous and obscurely dotted above or sometimes on both sides and variously pubescent below, shortly petiolate to almost sessile with scarcely more than the pulvinus, with subulate to setaceous stipules often fallen from herbarium specimens; hairs of the pubescence from very short in subsp. laevis to softly curved and c. $1 \mathrm{~mm}$ long in subsp. mitchellii. Inflorescences terminal or 
leaf-opposed, racemes with numerous, crowded flowers. Flowers deep yellow, pedicellate and bracteate. Calyx with teeth subequal and slightly longer than the tube, the tube slightly protracted on the lower side, the receptacle scarcely discernible. Standard more or less circular but often slightly broader than long, with a pair of plate-like calli, or linear converging thickenings, at the base of the lamina. Wings rounded-oblong. Keel with a rounded, right-angled bend about the middle, the beak twisted at the apex. Ovary glabrous, almost sessile, the style geniculate but scarcely constricted at the bend, the pod oblong-clavate, tapered to the base, the stipe lengthening to equal the calyx tube. Seeds 8-12 in the pod, slightly flattened, somewhat glossy, greenish grey, with a hooked radicular lobe.

Inflorescence usually less than $20 \mathrm{~cm}$ long, often $8-15 \mathrm{~cm}$. Flowers $7-10(-11)$ $\mathrm{mm}$ long, the pedicel slender, 1-3 $\mathrm{mm}$, in the axil of a small narrow bract (1.5-) 2-3 (-4.5) $\mathrm{mm}$ long. Calyx teeth (2-) $2.5(-5) \mathrm{mm}$, the tube (1.5-) $2(-3) \mathrm{mm}$ long, the receptacle to $1 \mathrm{~mm}$. Standard (5-) 6-7 (-9) $\mathrm{mm}$ long, (5-) 9 (-11) $\mathrm{mm}$ broad, the claw 1-2 mm. Wings 5-8 (-9) $\mathrm{mm}$ long, 2.5-4 $\mathrm{mm}$ broad, the claw 1.3-2 $\mathrm{mm}$. Keel (6-) 7-10 (-13) mm long, 3-4 (-5) mm broad, the claw 1.5-2 mm, the beak (4.5-) $6(-8) \mathrm{mm}$ long. Pod mostly $2-3 \mathrm{~cm}$ long, $(6-) 8(-10) \mathrm{mm}$ in diam. Seeds $\mathrm{c}$. $4 \mathrm{~mm} \times 3 \mathrm{~mm}$.

Distribution (see Map 2): Eastern Queensland, and the northern half of the Coast, Tablelands and Western Slopes in New South Wales.

C. mitchellii comprises two geographical races, one coastal in the northern and northeastern parts of the specific range, the other further south, often on the western slopes of the Great Dividing Range in southern Queensland and New South Wales, the races overlapping with considerable intergradation in southeastern Queensland and northern New South Wales; the relevant specimens are cited separately and shown on the map.

1. Stems pubescent, very rarely glabrescent; leaves large, $3-13 \mathrm{~cm}$ long, $2-5 \mathrm{~cm}$ broad, usually elliptical, acute or acuminate at the apex and tapered at the base, pubescent with loosely and irregularly arranged hairs on the underside; flowers in a very dense inflorescence, often with a thick peduncle and rachis............. subsp. mitchellii a.

1.* Stems glabrous or hoary, occasionally short-pubescent; leaves smaller or at least narrower, often $4-6 \mathrm{~cm}$ long and $1-1.5 \mathrm{~cm}$ broad, commonly narrow-obovate or narrow-elliptical with a more or less retuse or at least obtuse apex, glabrous or hoary below; flowers more widely spaced on a more slender peduncle $\ldots \ldots \ldots \ldots$ subsp. laevis $b$.

\section{2 i a subsp. mitchellii.}

Diagnostic characters as given in the key. Height of plants $0.3-1 \mathrm{~m}$, occasionally to $1.3 \mathrm{~m}$. Leaves large and soft, elliptical or narrow-elliptical (SAC 3-4, or 2), occasionally narrow-ovate (SAC 36-38) or nearly obovate (SAC 46-47), (4-) 5-8 (-14) cm long, (1.5-) 3-3.5 (-more than 5) cm broad; stipules 2-5 mm long. Inflorescences (6-) 8-13 (-18) cm long, on a rather thick peduncle up to $8 \mathrm{~mm}$ in diameter, with often more than 40 crowded flowers.

Distribution: From NE. Queensland (Cook District) to the North Coast of New South Wales, largely in coastal districts and on adjacent plateaux but extending inland to the Carnarvon Range and Maranoa District in Queensland; often on sandy and other light-textured soils, frequently near streams or behind beaches, sometimes in open forest or weedy in rough pasture or cultivation. 


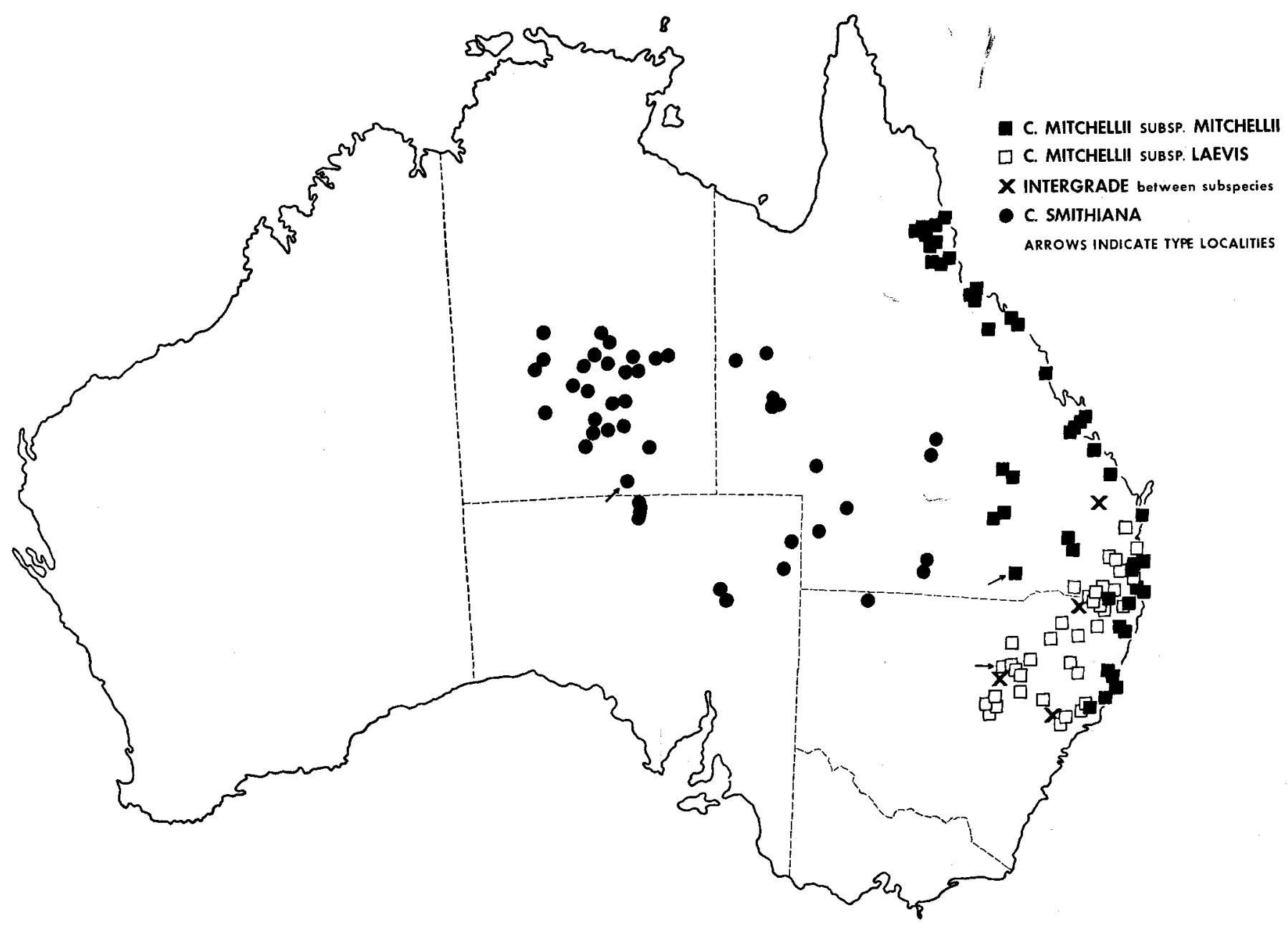

Map 2. Crotaluria mitchellii and C. smithiana. 
Specimens Examined: Queensland: Cook: Cairns, Betche NSW 45978, 8.1901 (NSW); Mareeba, Darnell-Smith NSW 45977, 4.1929 (NSW); Walsh R, c. 10 miles [c. $16 \mathrm{~km}$ ] E. of Dimbulah, Everist 5144, 5.1952 (BRI); Parada, along Walsh R, Keefer 3.1958 (BRI); Yungaburra, White 1.1918 (BRI). North Kennedy: Barron Beach (? loc.), Flecker 1614, 4.1936 (BRI); 6 miles [10 km] from Ravenshoe on Mt Garnet road, Davis 25, 3.1943 (NSW); Blunder Creek . . . area, c. 15 miles [c. $24 \mathrm{~km}$ ] SW. [? SE.] of Mt Garnet, Johnson 4.1964 (BRI); "Meadowbank", 45 miles [73 km] S. of Mt Garnet, Hoskin 5, 2.1963 (BRI); Cardwell, Michael 550 (BRI); 60 miles [97 km] SSE. of Mt Garnet, Clague 4.1971 (BRI); Magnetic I, White 2.1918 (BRI); Townsville, White 8.1916 (BRI, NSW 45979 with flowering shoot from Brisbane R); Animal Health Station, Oonoonba, $S / N 50 / 138,4.1950$ (BRI); 6 miles [10 km] W. of Ayr, Freshwater 8.1964 (BRI); Bowen District, Young (BRI); "Range View" c. 30 miles [c. $48 \mathrm{~km}$ ] SE. of Ravenswood, Everist 5183, 6.1952 (BRI); Edgecumbe Bay, Michael 1203 (BRI). South Kennedy: Perpetua Point, E. of Sarina, Francis 4.1927 (BRI). Leichhardt: Carnarvon Gorge, 70 miles [113 km] NNW. of Injune, McDonald 208, 4.1966 (BRI); Carnarvon Creek, Carnarvon Range, Butler 2.1960 (BRI). Port Curtis: beach c. $5 \mathrm{~km} \mathrm{~N}$. of Yeppoon, Rodd 1149, 8.1970 (BRI); Lamamou Beach near Yeppoon, $23^{\circ} 07^{\prime} \mathrm{S} 150^{\circ} 45^{\prime} \mathrm{E}$, Beeston 3.1971 (BRI); Rockhampton, Court 5.1925, Bailey (BRI); Marmor, near Rockhampton, Francis 3.1920 (BRI); Gladstone, Hedley 1888 (BRI); Rosedale, Dovey (BRI). Wide Bay: Wide Bay, Leichhardt NSW 114019, 5.1843 (NSW). Maranoa: "Rowallan", 2 miles [3 km] NE. of Mitchell, Martin 2.1962 (BRI); "Lagoonville", Orallo, Hando 1.1918 (BRI); Bokkara [Bokhara] Flats, Leichhardt NSW 115724, 2.1847 (or 1848) (NSW). Darling Downs: Chinchilla, Darnell-Smith NSW 45980, 4.1926 (NSW, "good match for the Type"*; Moonie R, 2 miles [3 km] S. of Weranga, Pedley 963, 2.1962 (BRI). Moreton: Moreton I, White Easter 1924 (BRI); Redcliffe (Moreton Bay), Bick 1.1917 (BRI); Nudgee, White 1.1918 (BRI); South Brisbane Cemetery, Balley (as F.M.B.) 3.1875 (BRI); South Brisbane, herb. Simmonds 97, 5.1889 (BRI); Brisbane R, Dietrich 836, 1863-5 (NSW); Cedar Creek, White 6.1913 (BRI); "Binnaburra", Macpherson Range, Johnson NSW 45981, 5.1951 (NSW). A specimen "Mouth of Althaus Creek, about 4 miles NW. of Yabulu [QueenslandNorth Kennedy] Smith T.131, 9.1942" (BRI), seems to have the dimensions of subsp. mitchellii but is almost completely glabrous; it is perhaps a local littoral ("on low dune") ecotype of which no other material is known.

New South Wales: North Coast: Tweed Heads, Forsyth NSW 45986, 10.1898 (NSW); Tooloom Scrub, 15 miles [24 km] SW. of Urbenville, Constable 6648, 12.1965 (NSW); Kyogle, Vane NSW 113906, 3.1961 (NSW); Jackadgery, W. of Grafton, Brooks NSW 113905, 2.1963 (NSW); Grafton [district], Glenfield Veterin. Res. Sta. SN 43/2404, 12.1943 (NSW); Willawarrin, Upper Macleay R, Noonan NSW 113904, 3.1964 (NSW); *Toorooka, Upper Macieay R, Noonan $N S W$ 45975, 4.1958 (NSW, "a reasonably good match for the Type"); Port Macquarie, Brown NSW 45988, 12.1897 (NSW); Kendall district, Bailey 86, 8.1929 (NSW); Craven State Forest [c. $13 \mathrm{~km}$ S. of Gloucester], de Beuzeville NSW 45989, 7.1917 (NSW).

2 i b subsp. laevis $A$. Lee, subsp. nov. HolotyPE: 1 mile $[1.6 \mathrm{~km}] \mathrm{W}$. of Baradine [New South Wales-North Western Slopes], P. Hodge NSW 84861, 6.1967 (NSW).

A subspecie mitchellii pubescentia minore vel absenti, foliis minoribus vel saltem angustioribus apicibus plerumque obtusis vel retusis, et saepe floribus paullo maioribus dissitioribusque, differt.

Diagnostic characters as given in the key. Differs from subsp. mitchellii also in intergrading characters: height of plants often c. $60 \mathrm{~cm}$. Leaves (30-) 51-65 (-80) $\mathrm{mm}$ long, (8-) $15(-28) \mathrm{mm}$ broad, usually narrow-elliptical (SAC 1-2) or a little broader, or occasionally obovate (SAC 46-47) or ovate (SAC 37); hairs of the pubescence grading in length and curvature from very short and nearly straight

\footnotetext{
* See Holotype paragraph.
} 
to the condition in subsp. mitchellii; stipules often present, $1.5-3 \mathrm{~mm}$ long. Inflorescence often with less than 30 flowers in the same length, the peduncle and rachis more slender than in subsp. mitchellii.

Distribution (see Map 2): From the Maranoa and Moreton Districts of Queensland to the Northern Tablelands, North Western and northern part of the Central Western Slopes, the eastern edge of the North Western Plains and the southern and inland parts of the North Coast of New South Wales; often on sandy or granitic (but not highly deficient) soils though occasionally on basalt, in open forest or woodland, sometimes near streams and occasionally weedy in pastures or cultivation, not known from the sea coast.

Specimens Examined: Queensland: Wide Bay: Gympie, Kenny (BRI); Archers Station, Durundur near Beerwah, Leichhardt NSW 45959 in part, 1.1844 (NSW). Darling Downs: Bungunyah, Everist 849, 12.1934 (BRI); Warwick, Boorman NSW 45982, 3.1911 (NSW); 7 miles [11 km] S. of Warwick, Pedley II59, 12.1962 (BRI); 15 miles [24 km] S. of Warwick on Stanthorpe road, Everist \& Webb 1276, 11.1946 (BRI); Inglewood, Jones (as W.T.J.) 1189, 3.1959 (BRI); Thulimbah, Schindler (BRI); Stanthorpe, Davidson 2.1891 (BRI), Boorman NSW 45983, 11.1904 (NSW), Hockings 2, 1.1963 (BRI). Moreton: Esk, Stone 10.1961 (BRI); Ipswich, Hall 154, 1909 (BRI); near Logan Village, McCarthy 1.1922 (BRI); 10 miles [16 km] NW. of Beaudesert, Henderson 11.1964 (BRI).

New Sourh WaLes: North Coast: Gloucester, Betche NSW 45990, 1.1881 (NSW); Glendon \& Singleton, Hunter R, Leichhardt NSW 45959 in part, 12.1842-1.1843 (NSW); Belford, Branxton District, Brown NSW 45994, 1.1954 (NSW). Northern Tablelands: c. 5 miles [c. $8 \mathrm{~km}$ ] past the Summit Border Gate on road to Maryvale [? error for Maryland], Morrow 39, 12.1961 (BRI); Track to Bald Rock Mtn, 15 miles [25 km] N. of Tenterfield, Constable 2078, 3.1962 (NSW); Boonoo Boonoo, Boorman NSW 45972, 2.1905 (NSW); Tenterfield to Sandy Flat, Maiden NSW 45967, 12.1898 (NSW); Deepwater, Fraser \& Vickery 1.1936 (SYD); Head of Gwydir R, Leichhardt NSW 45959 in part, probably 3-6.1843 (NSW); Mt Lindsay, Rupp NSW 45960, 4.1914 (NSW). North Western Slopes: Wallangra, Boorman NSW 45969, 11.1912 (NSW); Warialda, Rupp NSW 45974, 1.1907 (NSW); Terry Hie Hie, Inspector of Stock NSW 45962, 12.1910 (NSW); Pilliga Scrub, Rolls 56, 2.1974 (NSW); Dead Mans Waterhole, Pilliga Scrub, de Beuzeville NSW 45966, 11.1915 (NSW); Coonabarabran to Narrabri road, Althofer NSW $114108,2.1971$ (NSW); Teridgerie Creek, W. of Baradine, Constable NSW 45961, 3.1951 (NSW); Coolie Camp, Baradine, Chippendale \& Constable NSW 18539, 5.1951 (NSW); Baradine, Fraser NSW 45970, 1.1936 (NSW), Fraser \& Vickery 1.1936 (SYD), Rupp 12.1932 (SYD); first Moonbi hill, Martin 11.1967 (SYD, Pollen Sample 1388); Warrumbungles [Mits] near Coonabarabran, Hartley 36, 1.1966 (NSW); Coonabarabran, Nicholson NSW 45963, 2.1933 (NSW), Betche NSW 45993, 1.1883 (NSW); Coonabarabran to Timor Rock, Salasoo 2202, 1.1962 (NSW); Liverpool Plains, NSW 45965 (NSW). Central Western Slopes: Merrygoen, Brown NSW 45973, 6.1889 (NSW); Coolbaggie Creek, 2 miles [3 km] S. of Eumungerie, Constable 27, 12.1961 (NSW); Birriwa, Bowman NSW 116651, 3.1976 (NSW); Merriwa, Martin NSW 45971, 3.1911 (NSW); Narromine, Scott NSW 45992, 2.1915 (NSW), Hovenden NSW 45968, 2.1922 (NSW); Dubbo, Simmons NSW 113907, 2.1964 (NSW). Western Plains: annual weed collected in a regeneration plot, Narraway State Forest [c. $32 \mathrm{~km} \mathrm{W.} \mathrm{of} \mathrm{Coonamble],} \mathrm{Hoffman} \mathrm{NSW} \mathrm{45958,} 5.1957$ (NSW).

A few specimens intergrading between the subspecies (see Map 2) have been observed, as follows:

Queensland: Burnett: Gayndah, Kenny 1913 (BRI). Darling Downs: "Goondarin", Texas, Myring NSW 84682, 4.1967 (NSW); Wallangarra, Betche NSW 45985, 12.1891 (NSW), Boorman NSW 45984, 4.1914 (NSW). Moreton: $18 \mathrm{~km} \mathrm{S.} \mathrm{of} \mathrm{Esk,} \mathrm{Pedley} \mathrm{04003,} 12.1972$ (BRI).

New South Wales: North Coast: Bonalbo, Marks NSW 45995, 1.1915 (BRI, NSW); Barrington, Vickery NSW 121552, 2.1937 (NSW).

2 ii C. smithiana $A$. Lee, nom. et stat. nov. - C. mitchellii Benth. var. tomentosa Ewart in Proc. Roy. Soc. Victoria 19: 37 (1906); Ewart \& Davies, Fl. N. Territory: 141 (1917). Holoty PE: between the Finke R and Lady Charlottes Waters [Northern Territory-Central Australia], Kempe 23, 1885 (MEL 1010370). 
[C. mitchellii sensu auctt, non Benth.: Tate, Handb. Fl. Extratrop. S. Australia: 66, 223 (1890); Black, Fl. S. Australia 2: 306 (1924) and ed. 2, 2: 448 (1948); Gardner, Enum. P1. Austral. Occ.: 62 (1930); Poison Pl. Committee, CSIR, Pamph. 49: 26 (1934); Chippendale \& Murray, N. Territory Admin., Anim. Industr. Branch, Extens. Article 2 (II): 34 (1958); Beard, ed., (Descr. Cat.) W. Austral. Wildfl., ed. 2: 65 (1970). These authors here used C. mitchellii for that part of the mitchellii-smithiana complex occurring in the area they treated, viz. C. smithiana, although conflicting features of description and other implications are found in some of the references].

A soft-wooded subshrub with a strong tap root and, at first, an erect stem, later with several to many branches from near the base, ascending, procumbent or prostrate, often $30-50 \mathrm{~cm}$ long (including the short terminal inflorescences), greyish to bluish green due to the dense pubescence, drying pale, the hairs of the pubescence at first stiffly spreading then often downturned on the stems or loosely appressed on the leaves. Stems terete, sometimes with a fine, obscure ribbing under the dense, pale hairs. Leaves unifoliolate, stipulate and petiolate, the petiole articulate and usually angled on to a short petiolule, the joint somewhat obscured by the pubescence, the stipules very narrow, acute, at first erect then recurved to show the glabrous inner surface, the outer surface pubescent with long, spreading hairs. Leaflets mostly obovate to elliptical (SAC 3-4, 47-48), variable on the one plant, tapered at the base, at first densely tomentose on both sides, later the hairs less stiffly spreading and clearly sparse on the upper side which is sometimes almost or quite glabrous and then obscurely dotted, the apex obtuse or slightly emarginate, rarely broad-acute. Inflorescences ascending or erect, terminal on the branches and maturing basipetally, the somewhat crowded flowers pedicellate and bracteate, the bracts like the stipules but a little broader, the pedicels with stiffly spreading hairs. Flowers rather small, yellow, often with some reddish colour at the centre. Calyx more or less symmetrical, the teeth and tube nearly equal, the teeth triangular, the whole sparsely clothed with stiffly spreading hairs shorter than those of the stem and leaf. Standard nearly circular, sometimes with fine, dark stripes around the eye becoming obscure in most dried specimens, and with a pair of horizontal or rarely oblique calli extending downwards, but doubtfully into the claw. Wings more or less oblong with a very small auricle. Keel shortly beaked and with only a very slight twist at the apex, shortly fringed along the free margins of the petals near the base, with a pair of shallow pouches below the auricles. Ovary completely glabrous, or rarely with a very sparse scattering of minute hairs near the base of the suture, tapered into a very short stipe. Style downcurved, sometimes protruding through the base of the keel, then curving sharply erect, somewhat flattened, with a two-rowed beard, the adaxial row evident, the other sometimes obscure. Stigma terminal, brush-like. Pod inflated, glabrous, with only a few seeds (c. 4) in the few fruiting specimens seen, more or less clavate or sometimes truncate at the apex, the walls thin but firm, tapering at the base into a stipe about as long as the calyx tube. Seeds oblique-cordiform, light brown, slightly reddish, with a hooked radicular lobe.

Petiole 1.6-6 $\mathrm{mm}$ long, the petiolule 1-2 $\mathrm{mm}$; stipules $1.5-2.5 \mathrm{~mm}$ long. Leaflets (1-) 1.5-3 (-5) cm long, (0.6-) 1.3-2.5 (-3) cm broad. Inflorescences (3-) $5-10(-12) \mathrm{cm}$ long on peduncles of 1-2 cm. Flowers (4-) 6-8 (-10) $\mathrm{mm}$ long; pedicels $1.5-2.5 \mathrm{~mm}$; bracts $1.5-2.5 \mathrm{~mm}$ long. Calyx teeth mostly $2-3 \mathrm{~mm}$, about equal to the tube. Standard 5-7 $\mathrm{mm}$ long, 6.-7 $\mathrm{mm}$ broad the claw $1 \mathrm{~mm}$. Wings 5-6 mm long, the claw $1.5 \mathrm{~mm}$. Keel $6.5-8 \mathrm{~mm}$ long, c. $3 \mathrm{~mm}$ broad, the claw slender, 1-2 mm, the beak (4.5-) $6(-8) \mathrm{mm}$ long. Ovary 4-5 $\mathrm{mm}$, tapered into the 
stipe, c. $1 \mathrm{~mm}$ long. Pod usually $1.5-2 \mathrm{~cm}$ long, 5-9 $\mathrm{mm}$ in diam. Seeds $3.5-4.5$ $\mathrm{mm}$ long, $2.5-4 \mathrm{~mm}$ broad.

Distribution (see Map 2): On sands and sandy loams, often coarse-textured, of hills, creek beds and banks in Central Australia [Northern Territory], and in adjacent parts of Queensland and South Australia, extending into the extreme northwest of New South Wales.

Specimens Examined: Queensland: Gregory North: Box Flat near Georgina R, C[amp] 21 Simpson Desert Exped. 1939, Crocker 7.1939 (AD); 4 miles [6 km] from "Thorner" [Hut] on Dajarra road, Pedley 1113, 10.1962 (BRI); "Carandotta" Station, Everist \& Smith 158, 2.1937 (BRI); 5 miles [8 km] SE. of Boulia, Pedley 2010, 5.1966 (BRI); Boulia-Bedourie road, 5 miles [8 km] ex Boulia, Johnson 73/127, 9.1973 (NSW); Boulia-Bedourie road c. 20 miles [c. $32 \mathrm{~km}$ ] S. of Boulia, per Mahoney, 6.1953 (BRI); Currawilla, Everist 4081, 8.1949 (BRI). Mitchell: c. 15 miles [c. $24 \mathrm{~km}$ ] SW. of Yalleroi, Smith \& Everist 915, 10.1940 (BRI); 2.5 miles [4 km] SE. of Blackall, Everist 2586 (BRI). Gregory South: 60 miles [97 km] NE. of "Noccundra", Carolin 4275, 8.1964 (SYD); 35 miles [56 km] S. of Coopers Creek on road to Tibooburra (20 miles [32 km] to "Orientos" Station), Johnson 51, 6.1972 (NSW). Warrego: "Curragh", near Cunnamulla, Hubbard \& Winders 6242, 1.1931 (BRI); airfield 4 miles [6 km] W. of Cunnamulla, Ebersohn E 207, 4.1962 (BRI); “Carbean" near Cunnamulla, White 11800, 3.1941 (BRI).

New South Wales: Far Western Plains: "Thurlow Downs" to "Berrawinia Downs" in the Paroo R District, Boorman NSW 116467, 10.1912 (NSW); Toona gate NW. of Tibooburra, Milthorpe \& Cunningham 3421, 6.1975 (NSW).

South AUSTralia: Far North: c. 38 miles [c. $61 \mathrm{~km}$ ] E. of Dalhousie Springs, Lothian 1534" 8.1963 (AD); R[iver] Stevenson, Horn Exped. NSW 45786, 8.1894 (NSW); Lower part of R[iver] Stevenson, Tate? No. 865, 1894 (AD); "Macumba" Station, Ising 11.1950 (AD); near Macumba Hill, "probably Horn Exped." 5.1894 (AD); 38 miles [62 km] N. of camp on Strzelecki Creek, Milthorpe 3034, 10.1974 (NSW); Coopers Creek, $4 \mathrm{~km}$ downstream from Innamincka, Briggs 4619, 5.1972 (NSW); c. 60 miles [c. $95 \mathrm{~km}$ ] N. of Marree on Clayton R, Hill 479, 11.1955 (AD); Clayton R, c. 50 km NE. of Marree, Hill 319, 7.1955 (AD).

Northern Territory: Central Australia: Boomerang Waterhole, Lander R, 42 miles [68 km] NW. of Willowra, Chippendale NT 4761, 7.1958 (NSW, AD); Stirling Sandhills, 160 miles [258 km] N. of Alice Springs, Dale NSW 45781, 9.1939 (NSW); Wycliffe to Taylor Creek, Ewart 6.1924 (MEL); Barrow Creek, Chippendale NT 906, 3.1955 (BRI, NSW); c. 2 miles [c. $3 \mathrm{~km}$ ] NE. of "Ammaroo" homestead, Chippendale 8.1957 (AD); 19 miles [31 km] NE. of "Ooratippra" homestead, Swinbourne 577, 11.1962 (NSW); 9 miles [15 km] W. of "Ooratippra" homestead, Swinbourne 431, 9.1962 (NSW, MEL); 2 miles [3 km] N. of "Ti Tree Well" homestead, Winkworth 869, 3.1955 (BRI); Rockhole between Yuendumu and Cockatoo Creek [c. $270 \mathrm{~km}$ NW. of Alice Springs] (AD); Cockatoo Creek, Cleland 8.1931 (AD 95833039); 8 miles [13 km] NE. of "MacDonald Downs" Station, Perry 3405, 3.1953 (BRI, NSW, AD); "MacDonald Downs", Fraser R, Cleland 8.1930 (AD 95833048); Aileron Lagoon, Chippendale NT 4521, 6.1958 (MEL, AD); Irukaru Creek [tributary of Bundey R c. $145 \mathrm{~km} \mathrm{NE}$. of Alice Springs], Cleland 9.1930 (AD 95833047, bis); Plenty R road, 1 mile [2 km] N. of "Mt Riddock" homestead, Nelson NT 11981, 5.1966 (NSW, AD); Plenty R to Harts Range Depot, Burbidge \& Gray 4520, 10.1955 (AD); 6 miles [10 km] NE. of "Derwent", Winkworth 309, 6.1954 (BRI); "Napperby", c. 100 miles [c. $161 \mathrm{~km}$ ] NW. of Alice Springs, Everist 4207, 1.1950 (BRI); Alice Springs, Tate NSW 45790, 1894 (NSW, AD); 0.7 miles [1 km] N. of Bastard Bore, "Todd R" Station, Maconochie 469, 9.1967 (AD); 9 miles [15 km] W. of "Ringwood" homestead, Chippendale NT 4925, 9.1958 (BRI, NSW); Deep Well road, 13 miles [21 km] S. of Alice Springs, Nelson 1844, 1.1969 (BRI); Simpson Desert, $24^{\circ} 29^{\prime} \mathrm{S} 135^{\circ} 44^{\prime} \mathrm{E}$, Mitchell $71,8.1974$ (NT, NSW); SE. of "Henbury", Basedow 5-9.1920 (AD 96212262).

This species is named in honour of the late Lindsay Smith of the Queensland Herbarium, who had also recognized but not published it as distinct from $C$. mitchellii. 


\section{C. NOVAE-HOLLANDiAE (including C. CRASSIPES)}

In his treatment of $C$. novae-hollandiae DC. and C. crassipes Hook. in Flora Australiensis, Bentham divided the former into "three rather marked forms" and published their names as: a. parviflora, b. oblongifolia and c. lasiophylla. These can reasonably be considered to have the rank of forma. He also gave C. oblongifolia Hook. as a synonym of C. novae-hollandiae. He cited a number of specimens without referring these individually to the three forms, nor did he distinguish a Type forma in any way. From his inscription on the sheets at $\mathrm{K}$ however, it is possbile to allocate each of these specimens to the appropriate form, and these are accepted as the Types of Bentham's names. However, the characters of flower size and leaf pubescence which Bentham used to differentiate his three forms are not satisfactorily correlated in the larger collections now available. The species is now seen to fall clearly into two geographic races, treated as subspecies below, and all except one of Bentham's cited specimens fall into the Type subspecies. That specimen belongs to subsp. lasiophylla and is designated as its Lectotype below, since among the Syntypes of f. lasiophylla, Bentham included other elements which are referable to subsp. novae-hollandiae.

The rather sparse collections of subsp. novae-hollandiae from the Northern Territory and Western Australia show some variation suggesting that further collecting may reveal an east-west trend within that subspecies.

I have seen only a few specimens to which the name $C$. crassipes could be applied, two from Western Australia whence came the Type, the others from Queensland and the Northern Territory, and they differ from C. novae-hollandiae only in being glabrous. One collector remarks on the similarity between his specimens of glabrous and pubescent plants from the same locality, but notes that the specimens were collected from different soils. The stipule character described by Bentham for " $C$. crassipes" is seen in some but not all of the glabrous specimens and Bentham does not mention it for " $C$. novae-hollandiae" though it is similar there. There is variation in the shape of the leaflets in the glabrous specimens, as there is in those with pubescence, and within each of two Queensland localities (Lawn Hill, Tower Valley) glabrous and pubescent plants have been examined which are similar in leaf shape, although there is some difference in leaf shape between plants from the two localities. Thus, it seems that glabrous individuals or populations may occur in various parts of the range of subsp. novae-hollandiae but that they do not show sufficient coherence or distinctness to warrant formal taxonomic recognition.

3 C. novae-hollandiae DC., Prodr. 2: 127 (1825); Bentham, F1. Austral. 2: 181 (1864); F. M. Bailey, Queensland Fl. 2: 97 (1900); Domin in Biblioth. Bot. 22 $\left(89^{2}\right)$ : 733 (1925). HoLOTYPE: cited as "in Nova-Hollandia orient." A specimen in G-DC is accepted as the Type. Its label reads: "Nouvelle Hollande côte orient. Mus. de Paris 1822". Photograph only seen, a print at NSW. In spite of this citation, C. novae-hollandiae does not occur on the east coast of Australia. My interpretation of the identity of the Type has been confirmed by L. Pedley (pers. comm.) after examination of the specimen at G.

See under the subspecies for synonymy. 
[F. Mueller in Fragm. 3: 50 (1862) gives a description of C. novae-hollandiae (probably subsp. novae-hollandiae) erroneously under " $C$. mitchelli", as pointed out by Bentham, loc. cit. and Domin, loc. cit.].

Usually small shrubs to about $1.5 \mathrm{~m}$ in height, soft-wooded but probably perennial, with a more or less dense pubescence on some or most parts, or occasionally quite glabrous. Leaves unifoliolate, the petiole and usually shorter petiolule articulate and angled, stipulate with sometimes small and obscure or deciduous stipules; stipules always present on young stems but deciduous from the lower leaves, narrow, acuminate, erect then recurved, pubescent outside, glabrous within, often leaving a ridge, like that from the back of the petiole, decurrent on the stem (as described by Bentham for $C$. crassipes). Leaflets very variable in size and pubescence (see under the subspecies). Inflorescences terminal and leaf-opposed, the often numerous flowers somewhat variable in size and opening in basipetal or irregular order. Flowers yellow (a few, very old, with blackish discoloration? the "Fl. ex sicco vid. purpurascentes ..." of the Candolle's description), often fairly large, on ascending then recurved pedicels and subtended by small, acuminate bracts similarly erect then recurved. Calyx broadly campanulate with the tube slightly protracted on the lower side, the teeth subequal, narrow deltoid and often slightly longer than the tube, the whole variously pubescent or occasionally quite glabrous. Standard more or less circular but often slightly broader than long with a pair of plate-like calli at its base not extending into the claw, the apex sometimes broadly pointed. Wings rounded oblong. Keel with a rounded right-angled bend at or slightly below the middle, slightly but constantly twisted at the apex, usually with a pair of shallow folds or pouches near the auricle. Ovary glabrous to partly or entirely pubescent, the style more or less geniculate but scarcely constricted at the bend. Pod clavate or somewhat truncate, tapered into a short stipe. Seed yellow ochre, with a marked radicular lobe.

Leaflet often 3-5 $\mathrm{cm}$ long, $1-3 \mathrm{~cm}$ broad; petiole $5-15 \mathrm{~mm}$, petiolule $1.5-5 \mathrm{~mm}$; stipules $2-3 \mathrm{~mm}$ long. Flowers mostly $10-15 \mathrm{~mm}$ long, occasionally only $6.5-8 \mathrm{~mm}$, on pedicels of c. 4-8 mm with minute bracteoles near the middle; bracts $1-3 \mathrm{~mm}$. Calyx teeth (2.5-) 3-4 (-5) mm long, the tube (2-) $3(-4) \mathrm{mm}$. Standard (6-) 12 (-14) $\mathrm{mm}$ long, 8-14 $\mathrm{mm}$ broad, the claw mostly 1.5-2.5 $\mathrm{mm}$ long. Wings (6-) 9-12 mm long, the claw 1.5-3 mm. Keel (6.5-) 12 (-15) $\mathrm{mm}$ long, c. 5-7 mm broad, the claw 4-6 mm, the beak (3-) 4-6 (-7) $\mathrm{mm}$ long. Pod usually $2.5-3.5 \mathrm{~cm}$ long and c. $1 \mathrm{~cm}$ diam. Seeds c. $4 \mathrm{~mm}$ long, $3.5 \mathrm{~mm}$ broad.

Distribution (see Map 3): Northern Australia from Queensland, mostly west of the Great Dividing Range, to Western Australia and Central Australia.

The species comprises two geographic races: subsp. novae-hollandiae, in northwestern Queensland and the "Gulf country" of Queensland and the Northern Territory, and in comparable parts of Western Australia, and subsp. lasiophylla, limited to inland areas and known chiefly from Central Australia but occasionally overlapping the territory of subsp. novae-hollandiae near the Gulf of Carpentaria. There is apparently little intergradation between the subspecies, and the only specimen difficult to allocate is from this junction area: NORTHERN TERRITORY-Darwin \& Gulf District: Junction of McArthurs \& Glyde Rivers, Rice 2002, 9.1975 (NSW), shown as intergrade on Map 3. 


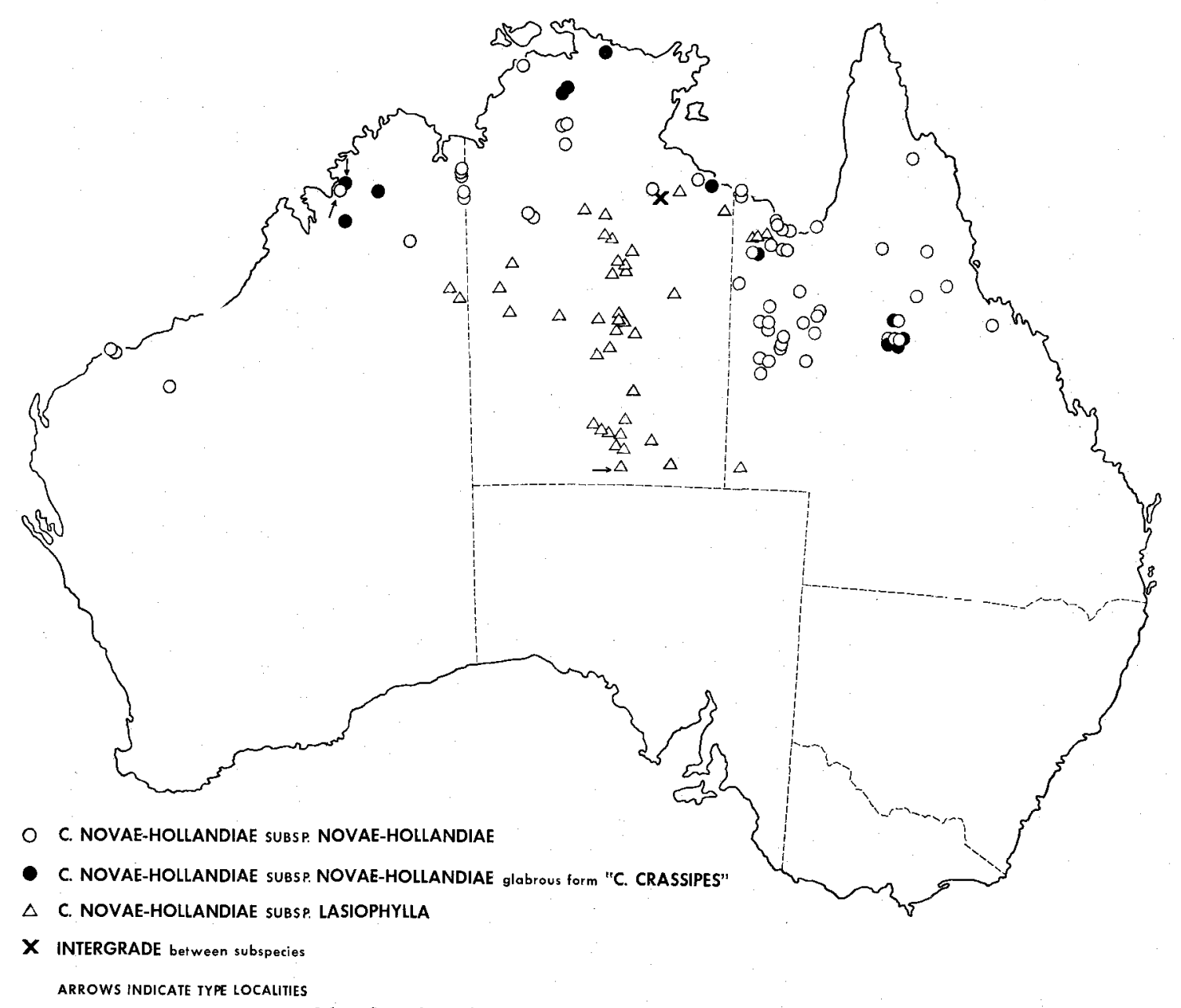

Map 3. Crotalaria novae-hollandiae (incl. C. crassipes) 
1. Leaflets elliptical to ovate or narrower, tapered into the petiolule at the base or occasionally approaching a cordate base, variously pubescent but often with the upper surface less densely clothed than the lower and sometimes quite glabrous above or on both sides; in the northern and northeastern parts of the range of the species

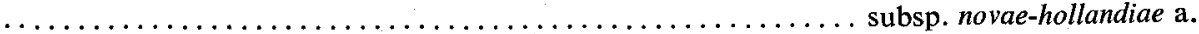

1.* Leaflets triangular or with a more or less cordate base, not tapered into the petiolule, densely pubescent on both surfaces with a grey tomentum becoming golden to deep reddish brown with long drying; in the inland, southern part of the range of the

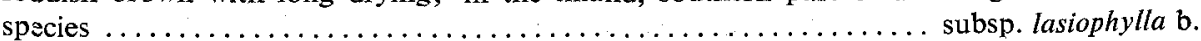

\section{3 a subsp. novae-hollandiae.}

C. crassipes Hook., Hooker's Icon. Pl. 9: t. 830 (1852); Bentham, Fl. Austral. 2: 182 (1864); Fitzgerald in J. \& Proc. Roy. Soc. Western Australia 3: 158 (1916-7); Ewart \& Davies, F1. N. Territory: 140 (1917); Gardner, Enum. Pl. Austral. Occ.: 62 (1930). HolotyPe, photograph only seen: North-east coast of Australia [Western Australia], Bynoe, Voyage of the Beagle (K, print at NSW of CSIRO Neg. No. Kew 1116).

C. novae-hollandiae f. parviflora Benth., loc. cit. IsosynTYPES: (i) Upper Victoria $\mathbf{R}$ [Northern Territory-Victoria R], Mueller 12.1855 (MEL 1010376, "seen by Bentham"; annotated "C. concinna F. Muell." [ined.] in a photograph of the sheet at K; (ii) Alligator Point [QueenslandBurke], scripsit Mueller (? MEL 1010371, "seen by Bentham").

C. oblongifolia Hook., Hooker's Icon. Pl. 9: sub t. 830 (1852).-C. novae-hollandiae f. oblongifolia Benth., Fl. Austral. 2: 182 (1864). HolotyPE, photograph only seen: N.W. Coast of Australia [Western Australia], Bynoe, Voyage of the Beagle (K-Herb. Hook., print at NSW of CSIRO Neg. No. 1115).

C. novae-hollandiae f. lasiophylla Benth., loc. cit., in part (see also subsp. lasiophylla), viz. as concordant with the following IsosYNTYPES: (i) Albert R [Queensland-Burke], Henne (MEL 1010374, "seen by Bentham"); (ii) Gulf of Carpentaria [as last], Henne (MEL 1010375, "seen by Bentham"); (iii) Gulf of Carpentaria [as last], Landsborough (MEL 1010377).

[C. mitchellii (as "Mitchelli") sensu auct., non Benth.: F. Mueller in Fragm. 3: 50 (1862); C. crassipes and C. oblongifolia are here said to be allied to subsp. novae-hollandiae under this misapplied name].

[C. novae-hollandiae var. novae-hollandiae; Chippendale in Proc. Linn. Soc. New South Wales 96: 239 (1972), nom. invalid.,-from the areas of occurrence given for this and for "var. lasiophylla" Benth., also listed, the names seen to have been confused, as well as being unpublished in varietal rank].

Diagnostic characters as given in the key; pubescence very variable in this subspecies, that of the stems moderately dense, greyish, of short simple hairs at first stiffly ascending, later curved upwards, becoming light brownish with drying and age, but rarely approaching the rich reddish brown seen in subsp. lasiophylla below, occasionally (in the form described as "C. crassipes") absent; rarely longer, spreading and downturned in zone of contact with subsp. lasiophylla. Leaflet narrow-oblong (SAC 13), narrow-ovate (SAC 37-38), narrow-elliptical (SAC 1-2) or almost narrow-trullate (SAC 55), or broader: elliptical, ovate to trullate, always tapered at the base except in a few specimens grading towards subsp. lasiophylla, the apex acute, obtuse or retuse; upper surface glabrous to densely pubescent, the lower always with some hairs except in the few completely glabrous specimens, and usually but not always more densely pubescent than the upper surface; minute dotting of both surfaces visible in sparsely pubescent or glabrous leaves. Calyx with rather sparse, appressed hairs. Recorded height of plants (40-) 45-60 (-75) cm. 
Distribution (see Map 3): Tropical Australia, widespread in the monsoon belt. Often in sandy soils and in burnt or disturbed weedy situations, also in red-brown loamy soils, some volcanics; not infrequently near streams.

Specimens Examined: QueEnsland: Cook: Kennedy R, Hann Exped. 380 (BRI); Lynbrook, Etheridge [railway] Line, Towers 4.1960 (BRI); Gilbert R, White 2.1922 (BRI, NSW 45776). Burke: Settlement Creek, Brass 48, 6.1921 (BRI); Settlement Creek, 35 miles [56 km] N. of Wollogorang, Perry 1200, 6.1948 (BRI); s. loc., Gittins 810, 6.1963 (BRI); Burketown (Q.)-Borroloola (N.T.) road, 25 miles [40 km] W. of Gregory R, Johnson 73/101, 8.1973 (NSW); Leichhardt R at "Floraville" crossing, Pedley 2098, 6.1966 (BRI); $17 \mathrm{~km} \mathrm{W.} \mathrm{of} \mathrm{Alexandra} \mathrm{R}$ on Cloncurry-Burketown road $18^{\circ} 35^{\prime} \mathrm{S}, 140^{\circ} 07^{\prime} \mathrm{E}$, Jacobs $1290,4.1974$ (NSW); 12 miles [19 km] W. of Alexandra R crossing on Cloncurry-Burketown road, Carolin 8856, 4.1974 (SYD, NSW); 3 miles [5 km] S. of "Armraynald", $17^{\circ} 36^{\prime} \mathrm{S}, 139^{\circ} 45^{\prime} \mathrm{E}$, Carolin 8929, 4.1974 (SYD, NSW); Lawn Hill, Jensen 69, $69 A^{*}$, 5.1940 (BRI); 10 miles [16 km] SSE. of "Morstone" Station, Perry 1055, 5.1948 (BRI); 6 miles [10 km] S. of "Boomarra" Station, Perry 3985, 8.1953 (BRI); "Chudleigh Park" Station, 110 miles $[117 \mathrm{~km}] \mathrm{N}$. of Hughenden, Hubbard \& Winders 7605, 2.1931 (BRI); c. $20^{\circ} 00^{\prime} \mathrm{S}, 139^{\circ} 50^{\prime} \mathrm{E}$, on "Calton Hills" Station c. 40 miles [c. $64 \mathrm{~km}$ ] N. of Mt Isa, Brown 8.1968 (BRI); 3 miles [5 km] N. of "Zingari" Station, Speck 4788, 8.1954 (BRI); Williams R, Macgillivray 2143, 8.1928 (BRI); 40 miles [64 km] ENE. of Richmond township, Speck 4477, 6.1954 (BRI)*; "Wongalee", c. 50 miles [c. $80 \mathrm{~km}$ ] N. of Hughenden, Hill 29, 30, 6.1968 (BRI); Cloncurry, Scarth-Johnson 530, 8.1970 (BRI); W. of Mt Isa, Beadle NSW 115727, 9.1972 (NSW); Mt Isa, Morris 5.1952 (BRI); Mt Isa district, Greig 11.1956 (BRI); Hann Highway, 4 miles [6 km] N. of Hughenden, Hill 1, 6.1968 (BRI); Galah Creek, Hughenden, McCarthy 89, 6.1933

(BRI); "Hughenden" Station, Inspector of Stock 5.1954 (BRI)*; Tower Valley, Hughenden, Sewell 5.1954 (BRI 126637, 004829*); 20 miles [32 km] NW. of McKinlay, per Forestry Commission of N.S.W. 2334 (NSW); 6 miles [10 km] W. of Mary Kathleen, Trapnell 16, 7.1958 (BRI); between Duchess and Mt Isa, Gittins 726, 5.1963 (BRI; NSW as: 2 miles [3 km] W. of Duchess); 100 miles $[161 \mathrm{~km}] \mathrm{S}$. of Cloncurry on the Longreach road, Jancey 5.1963 (SYD). North Kennedy: "Blue Range" Station via Ingham, per Newton 3.1953 (BRI); Ravenswood Junction, Hubbard \& Winders 6954, 1.1931 (BRI). Gregory North: 44 miles [71 km] SSE. of Mt Isa on the Dajarra-Mt Isa road, Williams 177, 10.1968 (BRI); "Ardmore", Everist 3188, 11.1947 (BRI); Dajarra, Everist \& Smith 139, 1.1937 (BRI); "Carandotta" Station, Everist \& Smith 158, 2.1937 (BRI). A depauperate specimen: "Rockmount", Helidon [Moreton], Klose 7.1963 (BRI) seems likely to have been introduced into this locality.

Northern Territory: Darwin \& Gulf District: 7 miles [12 km] E. of Rum Bottle Creek,

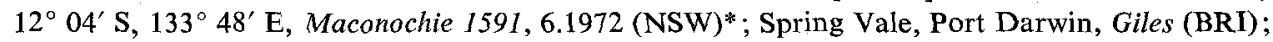

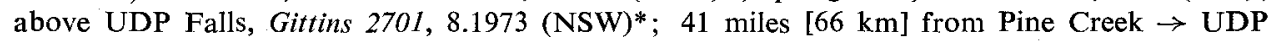
Falls, Gittins $2569,7.1973$ (NSW); 6 miles [10 km] N. of Katherine, McKee 8526, 2.1961 (NSW); Stuart Highway c. 3 miles [c. $5 \mathrm{~km}$ ] NW. of Katherine, Adams 881, 2.1964 (NSW); 30.2 miles [48.6 km] S. of Katherine town, Chippendale NT 3738, 9.1957 (NSW, MEL); Bryans Waterhole, 1 mile [1.6 km] off Carpentaria Highway, 18 miles [29 km] S. [E. by S. or W. by S. ?] of Borroloola, Johnson 73/117, 8.1973 (NSW); 36 miles [58 km] E. of "O.T. Downs" homestead, Chippendale NT 5529, 3.1959 (NSW); Tablelands Highway 9 miles [15 km] S. of Carpentaria Highway, Johnson 73/122, 8.1973 (NSW). ? Barkly Tableland: 3 miles [5 km] W. of Calvert $\mathrm{R}$ crossing, $17^{\circ} 13^{\prime} \mathrm{S}, 137^{\circ} 22^{\prime} \mathrm{E}$, Carolin 9257, 5.1974 (SYD, NSW). Victoria R District: N.T. Kimberleys, $14 \mathrm{~km} \mathrm{~W}$. of Victoria R crossing, Symon 10337, 6.1975 (NSW); 13.6 miles [22 km] S. of "Wave Hill" homestead, Chippendale NT 5761, 4.1959 (NSW).

Western Australia: Northern Province-Hann: Barnet R Gorge, $86 \mathrm{~km} \mathrm{~S}$. of Gibb R Crossing, Symon 10264, 5.1975 (NSW)*; $14 \mathrm{~km} \mathrm{~N}$. of Napier Range, $17^{\circ} 11^{\prime} \mathrm{S}, 124^{\circ} 51^{\prime} \mathrm{E}$, Symon 10139, 5.1975 (NSW)*. Ord: Around Kununurra, Ord Dam \& Wyndham road, $15^{\circ}$ $45^{\prime} \mathrm{S}, 128^{\circ} 44^{\prime}$ E, Scarth-Johnson 548, 9.1970 (BRI); Ord R, Fitzgerald NSW 45777 \& 45778 , 10.1906 (NSW); in Ord R, 69 miles [111 km] S. of Kimberley Research Station, Perry 2961, 7.1952 (NSW, BRI); 17 miles [27 km] NE. of "Springvale" Station, Lazarides 5062, 4.1955 (BRI). Fortescue: Nickol Bay, scripsit Maitland Brown (MEL 1010373 "seen by Bentham", and MEL 1010372); W. Australian Hamersleys, Yampire Gorge, Symon 10059, 5.1975 (NSW).

\footnotetext{
* Glabrous specimen ("C . crassipes").
} 
3 b subsp. lasiophylla (Benth.) A. Lee stat. nov.-C. novae-hollandiae f. lasiophylla Benth., Fl. Austral. 2: 182 (1864) as to the Lectotype (see also subsp. novaehollandiae). LectotyPe, here designated: near Mt Humphries, $25^{\circ} 38^{\prime}$ [Northern Territory-Central Australia], Macd. Stuart (MEL 1010378, "seen by Bentham").

[C. novae-hollandiae var. lasiophylla Tate, Part III (Sect. II, Botany): 152 (1896), in Spencer, ed., Rep. Horn Exped. Centr. Australia, nom. invalid.; Chippendale in Proc. Linn. Soc. New South. Wales 96: 239 (1972) -as for var. novae-hollandiae above, p. 350].

[C. novae-hollandiae sensu. auct, non DC. sensu str.: Black, Fl. S. Australia 2: 306 (1924) and ed. 2, 2: 448 (1948). Black here used the binomial for the only element of the species occurring in South Australia, viz. subsp. lasiophylla].

Diagnostic characters as given in the key; differs from subsp. novae-hollandiae also in its denser and more spreading tomentum, at first greyish, drying golden to deep reddish brown, the hairs c. $1 \mathrm{~mm}$ long, spreading and obliquely up- and downturned in a dense mass on stems and leaves; stem hairs occasionally as in subsp. novae-hollandiae (in zone of contact). Leaflets with a characteristic truncate or slightly cordate base, more or less triangular (SAC 75-76), the apex obtuse or slightly retuse, very variable in size on the one plant. Flowers and their parts like those of subsp. novae-hollandiae, but the calyx more densely pubescent with rather longer hairs.

Distribution (see Map 3): On sandy soils chiefly in eremean areas of the Northern Territory and in adjacent parts of Western Australia and Queensland; in the north of its range occasionally overlapping the territory of subsp. novae-hollandiae; perhaps to be expected in the far north of South Australia also.

Specimens Examined: Queensland: Burke: Gregory R. Crossing, c. 20 miles [c. $32 \mathrm{~km}$ ] SW. of Burketown, Pedley 2067, 6.1966 (BRI, K); Doomadgee Mission, Whitehouse (BRI), $17^{\circ} 56^{\prime} \mathrm{S}, 138^{\circ} 43^{\prime} \mathrm{E}$, Jacobs $1461,5.1974$ (NSW). Gregory South: Simpson Desert and many areas inland, Cockburn BPS 53, 7-8.1969 (BRI).

Northern Territory: Barkly Tableland: Settlement Creek, Brass 343, 5.1923 (BRI); 18 miles [29 km] W. of Stuart Highway, Top Spring beef road, Must 454, 2.1969 (BRI); 10 miles [16 km] N. of Elliott, Stuart Highway, Latz 95, $1.1968(B R I) ; 17$ miles [27 km] N. of "Helen Springs" Station, Perry 1908, 8.1949 (BRI); 15 miles [24 km] S. of Elliott, Byrnes 1441, 3.1969 (NSW); Renner Springs $18^{\circ} 20^{\prime} \mathrm{S}, 133^{\circ} 47^{\prime} \mathrm{E}$, Williams 81, 7.1975 (NSW); "Banka Banka" Station, Allen 661, 8.1922 (NSW); 50 miles $[80 \mathrm{~km}] \mathrm{N}$. of Tennant Creek, Perry CANB 603, 4.1948 (NSW, BRI); Gibson Creek, 19 $12^{\prime} \mathrm{S}, 134^{\circ} 08^{\prime} \mathrm{E}$, Must 22l, 7.1968 (NSW); 124 miles [199 km] W. of Camooweal in N.T., per N.S.W. Forestry Commission 2330, (NSW). Victoria River District: 40 miles [64 km] S. of Hookers Creek, Chippendale NT 2329, 7.1956 (NSW); 34.7 miles [55 km] NE. of Tanami, Chippendale 4.1959 (MEL). Central Australia: 15.4 miles [24.8 km] E. of The Granites, Chippendale NT 4275, 5.1958 (NSW, MEL); 69 miles [111 km] NW. of Willowra, Chippendale NT 4808, 7.1958 (NSW, MEL); "Numagalong" homestead, Nelson \& Swinbourne 32, 8.1965 (NSW, MEL); $14 \mathrm{~km} \mathrm{S.} \mathrm{of} \mathrm{Devils} \mathrm{Marbles,} 7 \mathrm{~km} \mathrm{~N}$. of Hurst Creek, Symon 10373, 6.1975 (NSW); "Singleton", 240 miles [386 km] N. of Alice Springs, Everist 1.1950 (BRI); 7 miles [11 km] S. of Wycliffe Well, Rose 11.1949 (BRI); "North Murray Downs", Filson 234, 5.1957 (MEL); Barrow Creek, Baldwin Spencer 1902 (MEL); "Central Mount Stuart", Ewart 6.1924 (MEL); 10 miles [16 km] S. of Wycliffe Well, Everist 4274, 1.1950 (BRI); 10 miles [16 km] E. of "Mt Riddock" homestead, Winkworth 606, 10.1954 (BRI); 40 miles [65 km] SE. of Alice Springs, Santa Teresa road, Latz 113, 1.1968 (NSW); 1 mile [1.6 km] N. of Renners Rock, Winkworth 34, 2.1954 (BRI, MEL); "Renners Rock" homestead, Winkworth $765,11.1954$ (BRI); Hugh R, 12 miles [19 km] NW. of "Maryvale" homestead, Nelson NT 11985 , 4.1966 (NSW); 0.6 miles [1 km] N. of Deep Well Siding, Nelson 1270, 8.1964 (NSW); 2 miles [3 km] N. of B.Indooma Siding, Swinbourne 419, 8.1962 (NSW); NW. Simpson Desert, Cockburn BPS 24, 7-8.1969 (BRI); 7.3 miles [11.7 km] SE. of Bottom Bore, Hale R, Chippendale NT 4931, 9.1958 (BRI, NSW). 
Western Australia: Eremean Province-Carnegie: $123 \mathrm{~km}$ WNW. of Tanami towards Billiluna, $128^{\circ} 30^{\prime} \mathrm{S}, 190^{\circ} 40^{\prime} \mathrm{E}$, Gittins $2324,7.1971$ (NSW); 78 miles [125 km] WNW. of Tanami $19^{\circ} 50^{\prime} \mathrm{S}, 129^{\circ} 50^{\prime} \mathrm{E}$ [? error for $128^{\circ} 50^{\prime} \mathrm{E}$ ], Dunlop 2333, 9.1972 (NSW).

\section{C. MEDICAGINEA OR C. TRIFOLIASTRUM}

Without adequate exotic material for comparison, it is impossible to evaluate critically the taxa denoted by these names, but at the Kew Herbarium, where there are larger collections from regions outside Australia C. medicaginea is recognized as a species distinct from C. trifoliastrum; also, in the most recent publication involving both names, de Munk (1962, below) accepts them as two species and introduces a new diagnostic character, viz. auricles present on the standard in C. trifoliastrum, absent in C. medicaginea.

In the past, however, other opinions have been held and published. The normal format of "synonymy" (which would be studded with "in part" qualifications), and "misapplied names", is abandoned here in favour of a chronological history of treatment and nomenclature of the plants involved.

The Australian plants referred to one or other of these names are represented in the Banks and Solander collection of 1770 (as C. trifoliastrum): NSW 133329 and 113929 from Thirsty Sound, Queensland, and the taxon, variable in itself, can therefore be accepted as native; nevertheless the possibility cannot be ruled out that other, morphologically different, plants were introduced subsequently. The legitimate names since applied to the taxon or taxa were not published for some years after that collection:-

1786 Crotalaria medicaginea Lamk., Encycl. Méth. 2: 201.

1802 Crotalaria trifoliastrum Willd., Sp. Pl. 3: 983.

1843 Bentham (in London J. Bot. 2: 578) noted that earlier writers had already confused the taxa. He recorded an Australian collection ["North Coast?"'] by Bauer under C. neglecta Wight et Arn., not $C$. medicaginea or $C$. trifoliastrum, and described a new species $C$. luxurians close to C. neglecta in flowers (but with these more numerous, and habit erect and more robust), from India.

1862 Mueller (in Fragm. 3: 56) referred specimens (Keppel Bay to Arnhem Land) to $C$. medicaginea, giving $C$. trifoliastrum as a synonym. He repeated this treatment in Fragm. 9: 157 (1875) for other specimens from Broad Sound, Peak Downs and Springsure.

1864 Bentham (in Fl. Austral. 2: 183) referred Australian plants (from northwestern Australia to Queensland) to C. trifoliastrum and specified distinctions from $C$. medicaginea. $\mathrm{He}$ made no mention here of $C$. neglecta.

1876 Baker (in Hook. f., Fl. Brit. India 2: 81) maintained C. medicaginea and trifoliastrum as species and reduced $C$. neglecta and $C$. luxurians to varietal rank under $C$. medicaginea.

1893 Moore and Betche (in Handb. F1. New South Wales: 145) referred New South Wales plants to $C$. medicaginea with $C$. trifoliastrum as a synonym.

1916 Maiden and Betche (in Census New South Wales P1.: 106) followed the last.

1925 Domin (in Biblioth. Bot. $22\left(89^{2}\right)$ : 734) referred Queensland plants to C. medicaginea, setting up two varieties to accommodate variation, including in the synonymy of one of them, var, australiensis Domin, a reference to Bentham's alleged misuse of the name $C$. trifoliastrum in Flora Australiensis. Domin considered this variety, the most common Australian form, close to C. luxurians Benth. in habit, and to C. trifoliastrum in its often multiflorous inflorescences. 
1962 de Munk (in Reinwardtia 6: 208) referred Malaysian plants, and a few specimens examined from Australia, to $C$. medicaginea, maintaining it as distinct from $C$. trifoliastrum, which latter he considered not to occur in Malaysia.

1963 Backer (in Fl. Java 2: 584) referred Javanese plants to C. medicaginea f. [sic] luxurians Baker, and did not include C. trifoliastrum as Javanese.

My interpretation of the foregoing is as follows: the name $C$. trifoliastrum is at present applied outside Australia to an erect, relatively large-flowered subshrub of limited geographical range in India, while $C$. medicaginea (including $C$. herniarioides Wight et Arn., C. neglecta and C. luxurians) is accepted for plants of varying habit, with usually (but not always) smaller flowers, distributed over a wide area from India through Malaysia to China and Australia and with the "luxurians" element extending farthest to the south and southeast, perhaps continued into Australia as Domin's var. australiensis. Until a critical appraisal of the whole situation is undertaken, I propose to use the name which has been most commonly used in publications by Australian botanists and which is indicated by the most recent work, i.e. C. medicaginea Lamk. In recent years most of the collections from tropical Australia have been distributed as $C$. trifoliastrum Willd., although the name $C$. medicaginea is in use at the Queensland Herbarium, where it is hoped that some investigation into variation in the Australian populations will be undertaken, since there is a large representation of this taxon in Queensland. Several variants have already been distinguished by L. S. Smith (1962), though under the name C. trifoliastrum. In New South Wales there are relatively few of these plants, and critical distinction of the variants is not considered as important as it is in northern Australia, where stockpoisoning properties have been found in some. I am greatly indebted to L. Pedley for his painstaking determinations of numerous specimens of this group submitted to him while at Kew. They included many of the known variants from States other than New South Wales and all were considered to belong to $C$. medicaginea.

Distribution: Widely distributed over northern Australia; in New South Wales occasional in drier parts of the North Coast, away from the sea, and one record from the North Western Slopes.

\section{SPECIES NATURALIZED OR ESCAPED FROM CULTIVATION IN NEW SOUTH WALES}

The species naturalized or adventive in New South Wales are grouped in the following list under the Sections enumerated in his recent classification of the African species by Polhill (1968), and a few brief notes are included where there have been recent changes in nomenclature.

Section Grandiflorae (Bak. f.) Polhill

C. agatiflora Schweinf.--cultivated and occasionally escaped.

Section Incanae (Benth.) Polhill

C. incana L. subsp. incana Z both subspecies naturalized subsp. purpurascens (Lamk.) Milne-Redh. $\int$ for many years.

C. goreënsis Guill. et Perr.-naturalized in Queensland, the Northern Territory and the Kimberleys of Western Australia, and appearing recently, probably as impurities in seed, in newly established "tropical" pastures in the North Coast of New South Wales. 
Section Macrostachyae (Benth.) Polhill

C. lanceolata E. Mey.-naturalized.

C. pallida Ait. var. obovata (G. Don) Polhill-naturalized. This taxon has previously been identified at the National Herbarium of New South Wales by the synonyms C. striata DC. and, later, C. mucronata Desv.; earlier it was misidentified as the distinct species $C$. saltiana Andr. (see Senn in Rhodora 41: 356 (1939).

C. zanzibarica Benth.- - naturalized. A few specimens were formerly identified as C. usaramoensis Bak. f., now regarded as a synonym.

Section Calycinae Wight et Arn.

C. juncea L.- an apparently temporary occurrence on the Clarence River at Upper Copmanhurst in 1910, but not collected since in New South Wales.

\section{Section Crotalaria}

C. grahamiana Wight et Arn.-naturalized. This species has previously been misdetermined in New South Wales as C. quinquefolia L.

C. semperflorens Vent.-cultivated and occasionally escaped.

C. spectabilis Roth-naturalized. For many years this species was confused with the native species $C$. retusa L., but our earliest specimen from a New South Wales locality is dated 1912 and described as a naturalized weed.

C. distans Benth.--apparently cultivated and occasionally escaped.

C. macaulayae Bak. f.- - a single collection said to have been introduced as an impurity in seed.

C. virgulata Klotsch-cultivated and occasionally escaped.

\section{ACKNOWLEDGEMENTS}

I am indebted to the Directors of the National Herbarium of Victoria and the Queensland Herbarium, and to the Keeper of the State Herbarium of South Australia, for valuable loans. In 1974 I was able to examine material at the Kew Herbarium, including the Type of $C$. dissitiflora, while assisted by a grant from the Australian Biological Resources Study; thanks are also due to the Director and staff of the Kew Herbarium, and especially to Dr R. M. Polhill.

The abundance of material made available to me has permitted some confidence in the sorting adopted and in the nomenclature applied, and this confidence had been increased by the general agreement of Mr Les. Pedley of the Queensland Herbarium, who had intended to continue the unpublished work of his colleague, the late $\mathrm{Mr}$ Lindsay Smith. However, in view of my own progress at the time of Smith's death, Pedley generously assisted me with determinations, information and discussion in correspondence, while serving as Australian Botanical Liaison Officer at Kew. After the death of Smith in 1970, I found that he had been pursuing investigations similar to mine over a number of years, and had incorporated similar conclusions in a key constructed for use in the Queensland Herbarium. It is a pleasure to acknowledge 
the support given by his work, even though my treatment differs somewhat from his, particularly in nomenclature. Smith's greater experience in the field yielded information about soil types, the importance of which $I$ had not at that time fully recognized, nor had I looked closely into subdivisions of the species $C$. linifolia and $C$. medicaginea which figure in his key, and these last problems, less pertinent to the Flora of New South Wales, remain for his successor.

I am also indebted to Dr L. A. S. Johnson for a critical review of the content of this paper, and for many constructive suggestions for the improvement of its presentation.

The figures were prepared for publication by Christine Payne and the maps by Rhonda Barry.

\section{LITERATURE CITED}

Jackson, E. A., 1962--Soil Studies in Central Australia. CSIRO Soil Publication No. 19.

Litchfield, W. H., 1969 -Soil Surfaces and Sedimentary History near the Macdonnell Ranges, N.T. CSIRO Soil Publication No. 25.

Polhill, R. M., 1968-Miscellaneous Notes on African species of Crotalaria L. II. Kew Bull. 22: 169-348.

Smith, L. S., 1962--Unpublished key to Crotalaria, in BRI.

Stephens, C. G., 1961-The Soil Landscapes of Australia. CSIRO Soil Publication No. 18.

Stephens, C. G., 1963-Soils, 2nd. ed.: 18, in Atlas of Australian Resources, 2nd. Series. Canberra.

Systematics Association Committee, 1962-Descriptive Terminology, Chart 1a. Taxon 11: 246-247. 